\title{
Article \\ A Case Study on the Danube Limes in Serbia: Valorisation and Cartographic Analyses of Selected Tourism Products
}

\author{
Jasmina M. Jovanović ${ }^{1}$, Marko Stojanović ${ }^{2,3, *}$, Tanja Janković ${ }^{1}$, Siniša Drobnjak ${ }^{2,3}{ }^{\oplus}$, Dejan Djordjević ${ }^{2,3}$, \\ Radoje Banković ${ }^{2,3}$, Milan Radovanović ${ }^{4,5}$, Ljiljana Živković ${ }^{1}$, Tamara Gajić ${ }^{4,5}$, Dunja Demirović Bajrami ${ }^{4,5}$, \\ Tatiana N. Tretiakova ${ }^{5}$ and Julia A. Syromiatnikova ${ }^{5}$
}

1 Faculty of Geography, University in Belgrade, Studentski trg 3/III, 11000 Belgrade, Serbia; jasmina.jovanovic@gef.bg.ac.rs (J.M.J.); tanja.jankovic115@gmail.com (T.J.); ljiljana.zivkovic@gef.bg.ac.rs (Lj.Ž.)

2 Military Geographical Institute, Mije Kovačevića 5, 11000 Belgrade, Serbia; sinisa.drobnjak@vs.rs (S.D.); dejandjodjevic.vgi@gmail.com (D.Dj.); radojebankovic@yahoo.com (R.B.)

3 Military Academy, University of Defense, Veljka Lukica Kurjaka 33, 11000 Belgrade, Serbia

4 Geographical Institute "Jovan Cvijić" SASA, Djure Jakšića 9, 11000 Belgrade, Serbia; m.radovanovic@gi.sanu.ac.rs (M.R.); tamara.gajic.1977@gmail.com (T.G.); d.demirovic@gi.sanu.ac.rs (D.D.B.)

5 Institute of Sports, Tourism and Service, South Ural State University, 76 Lenin Ave., 454080 Chelyabinsk, Russia; ttn1@mail.ru (T.N.T.); syromjatnikowa@mail.ru (J.A.S.)

* Correspondence: stojanovicm80@yahoo.com; Tel.: +381-60-55-11-008

\section{check for}

updates

Citation: Jovanović, J.M.; Stojanović, M.; Janković, T.; Drobnjak, S.;

Djordjević, D.; Banković, R.;

Radovanović, M.; Živković, Lj.; Gajić,

T.; Demirović Bajrami, D.; et al. A

Case Study on the Danube Limes in

Serbia: Valorisation and Cartographic

Analyses of Selected Tourism Products. Sustainability 2022, 14, 1480. https:// doi.org/10.3390/su14031480

Academic Editor: Mark A. Bonn

Received: 28 November 2021

Accepted: 18 January 2022

Published: 27 January 2022

Publisher's Note: MDPI stays neutral with regard to jurisdictional claims in published maps and institutional affiliations.

Copyright: (C) 2022 by the authors. Licensee MDPI, Basel, Switzerland. This article is an open access article distributed under the terms and conditions of the Creative Commons Attribution (CC BY) license (https:// creativecommons.org/licenses/by/ $4.0 /)$.

\begin{abstract}
Cultural assets in the area of the Danube Limes in Serbia are an integral part of the world heritage "Roman Empire Borders". The research presented in this paper includes the tourist and cartographic visualization of 19 Roman sites in the Danube Limes region of Golubac-Radujevac, to determine the real possibilities of tourism development in this area. The historical and cultural heritage of this area is among the most attractive tourist destinations in Serbia, Djerdap National Park and Djerdap Geopark. Despite its diverse cultural and historical values and the specific and unique natural environment, this area is not sufficiently used for tourism. The research included the evaluation of localities, which may serve as the basis to establish which activities should be undertaken in order to plan, use, preserve, and protect such important cultural assets, under the principles of sustainable tourism development. Information based on spatially referenced data in the research process requires cartographic support, in order to understand the geospatial relations of the site significance. Cartographic visualization enabled efficiently systematized data organization, spatial identification, presentation, and the use of complex information from the mapped area in the data analysis in this paper.
\end{abstract}

Keywords: tourist valorization; cartographic visualization; cultural and historical heritage; danube limes

\section{Introduction}

The valorization of ancient civilizations' cultural heritage potential and the awareness of its protection and preservation when being used for tourism holds major societal significance. Understanding the value of heritage in a societal, cultural, economic, and environmental sense bears significance for establishing prerequisites for its preservation in the future. "Understanding the value, role, and place of the individual localities of historical significance cannot be achieved without comprehending and understanding a broader area and heritage" [1] (p. 39).

Heritage is a significant factor of spatial transformation and a foundation for tourism development. The Danube Limes tourist area in Serbia's Golubac-Radujevac region, "represents an area with a high concentration of natural and anthropogenic tourist resources in different degrees of protection, preservation, and valorization for the needs of tourism development" [2] (p. 12). The identification of Roman sites along the Danube Limes in Serbia, as the basis of a tourist resource, is of special cultural and historical significance. 
The study's goal is to identify real opportunities for tourism development in the Golubac-Radujevac region. The high tourist potential of this area is additionally defined by the fact that its cultural assets are an integral part of the world heritage "Roman Empire Borders". In addition to its location within the Danube Limes in Serbia, the attractiveness and importance of the cultural assets of the Golubac-Radujevac region greatly contribute to the natural specifics of the Djerdap Gorge. The authenticity of Djerdap National Park and Djerdap Geopark contributes to the better promotion of these sites. The research includes 19 sites in the Danube Limes in Serbia. Within the Djerdap Geopark, there are 14 sites, 12 of which belong to the Djerdap National Park. The other five Limes sites are located in the functional hinterland of the geopark.

The complexity of the problems regarding the development of this tourist area requires the existence of an objective and clear analysis of existing potential and their specifics in terms of possibilities for future development. Numerous planning documents of national importance have been produced in order to plan, protect, and manage the development of tourist destinations in the Danube Limes in Serbia, which includes the region of GolubacRadujevac. Spatial and master plans of the area define the basic goals necessary for the development of the tourism sector in Serbia. The defining goals, in the context of sustainable tourism development, are implemented through plans separated into four groups: cultural, economic, social, and goals related to the environment of tourist destinations. Each group entails general goals of sustainable development, which are mutually complementary [2-4]. Starting from the goals of sustainable development, the research in this paper includes 29 indicators in the evaluation of cultural assets of the Danube Limes in Serbia's GolubacRadujevac region. The selection of the Hilary Du Cros [5-7] model of tourist valorization has facilitated the evaluation and, therefore, the realization of the given guidelines within the existing planning documents. The complexity of the valorization of cultural assets within the Danube Limes in Serbia, as a whole, indicates the selection of the Hilary du Cros model. In other words, the selection of the valorization model is implied by the specific traits of these assets (location, historical national and international significance, etc.). A comprehensive analysis and interpretation of the cultural assets' significance in the Danube Limes in Serbia, by the means of a set of interconnected indicators (cultural, economic and social) of tourism valorization, enable the comprehension of the dimensions of sustainable development of tourism within this area. According to the valorization and indicator analysis results (summary and individually) for all localities, the potential of cultural assets are indicated as the resources for sustainable development and improvement of the quality of life for the population in this area. Here, we need to note the importance of encompassing a social dimension in the activities on the cultural assets' improvement and protection, together with the value of the very assets that impact the economic development and quality of life of the local population.

Value of cultural assets implies the method of assets' use (utility value), attractiveness (formal value), and links to the community (symbolic value) [8,9]. "It is necessary to examine the relationship between the heritage and its value, tourism, and perception of the local community, as the host of the destination and the initiator of active participation in the cultural tourism development in their territory" $[9,10]$. The valorization of cultural heritage, subject to the requirements and needs of modern society, requires building awareness of heritage and social needs. The activities related to the decision-making about cultural heritage preservation and incentivizing tourism development need to be attuned to the needs of individuals and their communities. The tourism values of cultural assets yield the possibility for the development of services that benefit society [9].

The historical and societal context of understanding the value, significance, and respect for cultural heritage requires an active consideration of topics on heritage and its greater inclusion in daily life. The International Centre for the Study of the Preservation and Restoration of Cultural Property (ICCROM) stipulates: "The importance of cultural heritage preservation is implied not only from the perspective of the material heritage but 
also in the field of preservation and raising awareness on the heritage as the means for improving the livelihoods" $[9,11]$.

The process of planning and using space as a basic tourist resource and as part of sustainable development makes the support of appropriate information necessary. A map, as a source of information, enables efficient geospatial analysis. Cartographic presentations of the tourism development potential of a given territory require the visualization of geodata unified from various sources [12]. The knowledge of geospace obtained through research and presentation by means of visual identification provides for the appropriate valorization of its components. Through mapping procedures and the interpretation of map content, geoinformation (location and attributive) is spatially identified clearly and obviously in their interdependence. The spatially organized and graphically presented information on the sub-indicators of tourist valorization in this paper aim to clearly represent the properties of the resources within the area of interest. Visual identification of the characteristics of the state and the structure of the set of sub-indicators was obtained by producing maps and interpreting geodata. The translation of data text $\rightarrow$ table $\rightarrow$ map $\rightarrow$ text was carried out. This made it easier and clearer to identify development priorities, i.e., activities that needed to be planned and undertaken. Visualization, in addition to processing and converting numerical data into an image, enables the choice of display modes, focusing on specific aspects of geodata.

\section{Danube Limes in Serbia, Sector Golubac-Radujevac}

The Roman Limes, or the border of the former Roman Empire, extended over $5000 \mathrm{~km}$ and passed through the lands surrounding the Mediterranean Sea (Mare Nostrum). It is thus one of the largest and longest cultural heritage monuments in the world. The border of the Roman Empire stretched from the Atlantic Ocean, through Europe to the Black Sea, the Middle East to the Red Sea and from there through North Africa to the Atlantic coast. Part of the border ran along the Danube River, from Germany to the Black Sea until 106 AD when Dacia was included as a Roman province, then it moved even deeper towards the Carpathian Mountains [13].

The borders of the Roman Empire are a world heritage site. The first on that list since 1987 was Hadrian's Wall; the Upper German-Recian Limes was included in 2005, Antonin's Wall in 2008, and after that, other numerous places along the Roman Limes have been included [14]. According to the definition by the Bratislava Group, as the coordinating working group of countries for the nomination of the preserved borders of the Roman Empire in their territories (Austria, Croatia, Germany, Hungary, Slovakia, and Great Britain) from 2003: "borders at the peak of the Empire, from Trajan to Septimius Severus (c. 100 to $200 \mathrm{AD}$ ) along with military facilities from other periods along the border. Buildings include fortresses, fortifications, towers, the road running along with the Limes, artificial barriers and related civilian structures" [13] (pp. 10,11).

Within the borders of the Roman Empire, the Danube Limes is a unique archaeological site in Europe and a monument of international importance. It includes valuable sites of cultural heritage along the Danube connected to a single unit. Archaeological heritage sites along the border of the Roman Empire in the Serbian Danube region are an integral part of the Danube Limes. As a result of this, the Danube Limes in Serbia, as a site with traces of Roman military presence, has been nominated to be included in the list of monuments under the protection of UNESCO. The Danube Limes in Serbia has been included in the tentative list of the Borders of the Roman Empire of World Heritage since 2020 [15,16].

The International World Heritage Site, within the "Borders of the Roman Empire", covers $450 \mathrm{~km}$ of the Danube Limes in Serbia. Limes in Serbia include 4 larger units: I- Lower Pannonian part (from Neštin to Zemun/Taurunum), II-Upper Moesian part (from Belgrade/Singidunum) to Golubac/Cuppae, III—Djerdap gorge, and IV—from Kostol (Pontes) to Radujevac (Negotin) [13,17]. The Danube Limes in Serbia, which include cultural assets in separate characteristic units such as: III—Djerdap gorge and IV—from 
Kostol (Pontes) to Radujevac (Negotin), are territorially defined as the region of GolubacRadujevac and is the subject of research in this paper.

Part of the Danube Limes in Serbia's Golubac-Radujevac region includes 19 localities: 1. Cuppae-Golubac, 2. Roman Road, 3. Novae-Čezava, 4. Cantabaza-Saldum, 5. Ad Scrofulas-Bosman, 6. Roman Road and Imperial Inscriptions, 7. Smorna-Boljetin, 8. Campsa-Ravna, 9. Gerulata-Miroč, 10. Hajduk Mill, 11. Tabula Traiana-Trajan's Plaque, 12. Diana-Zanes-Karataš, 13. Pontes-Kostol, 14. Konopište-Mala Vrbica, 15. GlamijaRtkovo, 16. Egeta-Brza Palanka, 17. Mora Vagei-Mihajlovac, 18. Aquae-Prahovo and 19. Ćetače-Radujevac. The included parts of the Danube Limes from Golubac to Radujevac belong to the municipalities: Golubac (localities 1-6), Majdanpek (localities 7-9), Kladovo (localities 10-15), and Negotin (localities 16-19). At the same time, sites 1-12 of the analyzed limes are located within the Djerdap National Park and sites 1-14 within the Djerdap Geopark. Locations 15-19 are not part of the geopark but are functionally related to other cultural assets (Table 1).

Table 1. Cultural assets of the Danube Limes in Serbia, sector Golubac-Radujevac.

\begin{tabular}{|c|c|c|c|c|c|}
\hline & Territory & & Name & Description & Municipality \\
\hline \multirow{19}{*}{ 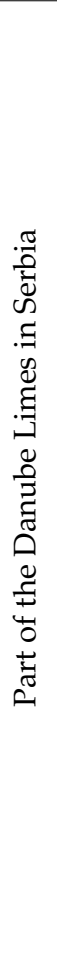 } & \multirow{14}{*}{ 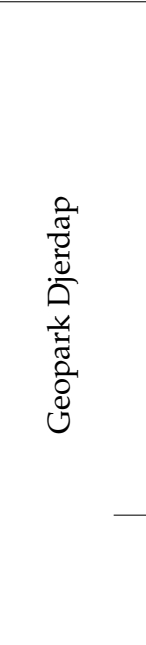 } & \multirow{14}{*}{ 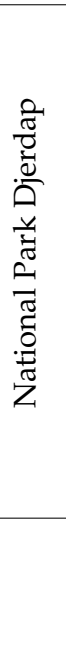 } & 1. Cuppae-Golubac & Fort & Golubac \\
\hline & & & 2. Roman Road & Beneath Golubac City fortress & Golubac \\
\hline & & & 3. Novae-Čezava & Fort & Golubac \\
\hline & & & 4. Cantabaza-Saldum & Fort & Golubac \\
\hline & & & 5. Ad Scrofulas-Bosman & Fort & Golubac \\
\hline & & & 6. Roman road and Imperial Inscriptions & Gospođin vir & Golubac \\
\hline & & & 7. Smorna-Boljetin & Fort & Majdanpek \\
\hline & & & 8. Campsa-Ravna & Fort & Majdanpek \\
\hline & & & 9. Gerulata-Miroč & Fort & Majdanpek \\
\hline & & & 10. Hajduk Mill & Fort & Kladovo \\
\hline & & & 11. Tabula Traiana-Trajan's Plaque & $\begin{array}{l}\text { Roman road and imperial } \\
\text { Plaque-inscription }\end{array}$ & Kladovo \\
\hline & & & 12. Diana-Zanes-Karataš & Fort & Kladovo \\
\hline & & & 13. Pontes-Kostol & Trajan's Bridge and Fortress & Kladovo \\
\hline & & & 14. Konopište-Mala Vrbica & $\begin{array}{l}\text { Military complex and location for } \\
\text { Limes troops' provisions }\end{array}$ & Kladovo \\
\hline & & & 15. Glamija-Rtkovo & $\begin{array}{l}\text { Minor fort under the procedure of } \\
\text { cultural asset designation }\end{array}$ & Kladovo \\
\hline & & & 16. Egeta-Brza Palanka & Three forts & Negotin \\
\hline & & & 17. Mora Vagei-Mihajlovac & $\begin{array}{l}\text { Minor fort under the procedure of } \\
\text { cultural asset designation }\end{array}$ & Negotin \\
\hline & & & 18. Aquae-Prahovo & Late-antique period town & Negotin \\
\hline & & & 19. Ćetače-Radujevac & $\begin{array}{l}\text { Minor fort under the procedure of } \\
\text { cultural asset designation }\end{array}$ & Negotin \\
\hline
\end{tabular}

The Roman Limes in Serbia consist of fortifications and other military facilities on the right bank of the Danube, which represent material heritage of exceptional importance. The most famous and most attractive part of the Limes is in the area of Djerdap, with numerous localities (unit II, part of the Danube Limes in Serbia). The physiognomy of the Djerdap Gorge influenced military control in the area. Smaller fortifications, which were easier control, were built in the narrower part of the gorge and were intended for auxiliary military troops. Downstream from the gorge, the widening of the valley provided for larger fortifications. The Djerap gorge, as the longest composite valley in Europe (100 km), consists of four gorges (Golubačka, Gospodjin vir, Kazan and Sipska) and three valleys (Ljupkovska, Donjomilanovačka and Oršavska). Numerous sites from that period were flooded in the 20th century due to the construction of the dams, HPP Djerdap I and II.

The construction of a Roman road and a large number of fortifications indicate the importance of Djerdap for the Roman Empire. This area had military and traffic significance in the periods when it existed as a border area of the Roman Empire. The Roman Roads, 
Trajan's tablet, and Trajan's bridge are symbols of man's first victory over the Djerdap gorge and the most important works of Roman construction. During the period of Dacia's annexation, when this area lost its primary military significance, trade developed in the places where military fortifications were built, helping them to gain broader economic and cultural significance [3].

Djerdap National Park covers an area of $638 \mathrm{~km}^{2}$ (south-eastern part of Europe, northeastern part of Serbia, the border between Serbia and Romania). It represents a composite of unique geographical features, specifically beauty and fascination, cultural and historical values of ancient civilizations, and rare natural ecosystems. Specific natural geomorphological features (Djerdap gorge) such as climate, vegetation, phenomena, as well as archaeological sites (Trajan's Plaque, Roman Road, Diana, Pontes, etc.) and cultural and historical monuments helped the area to achieve the status of the National Park in 1974. This area includes 12 sites from the Golubac-Radujevac region: 1. Cuppae-Golubac, 2. Roman Road, 3. Novae-Čezava, 4. Cantabaza-Saldum, 5. Ad Scrofulas-Bosman, 6. Roman Road and Imperial Inscriptions, 7. Smorna-Boljetin, 8. Campsa-Ravna, 9. Gerulata-Miroč, 10. Hajduk Mill, 11. Tabula Traiana -Trajan's Plaque, 12. Diana-Zanes-Karataš. Its international and national importance as a tourist area is contributed by the international waterway, Corridor VII and the connection with traffic Corridor X.

The area of the Djerdap Geopark, as a natural asset in Serbia, was included in the UNESCO GLOBAL GEOPARKS list in 2020. It covers an area of $1330 \mathrm{~km}^{2}$, which includes the area of Djerdap gorge and its hinterland (Djerdap National Park $638 \mathrm{~km}^{2}$ and broader hinterland $692 \mathrm{~km}^{2}$ ), which are administratively located in parts of the municipalities: Golubac, Majdanpek, Kladovo, and Negotin (Figure 1). In addition to the 12 sites from the Golubac-Radujevac region, which are included in Djerdap National Park, it has two additional sites: Pontes-Kostol, and Konopište-Mala Vrbica are included.

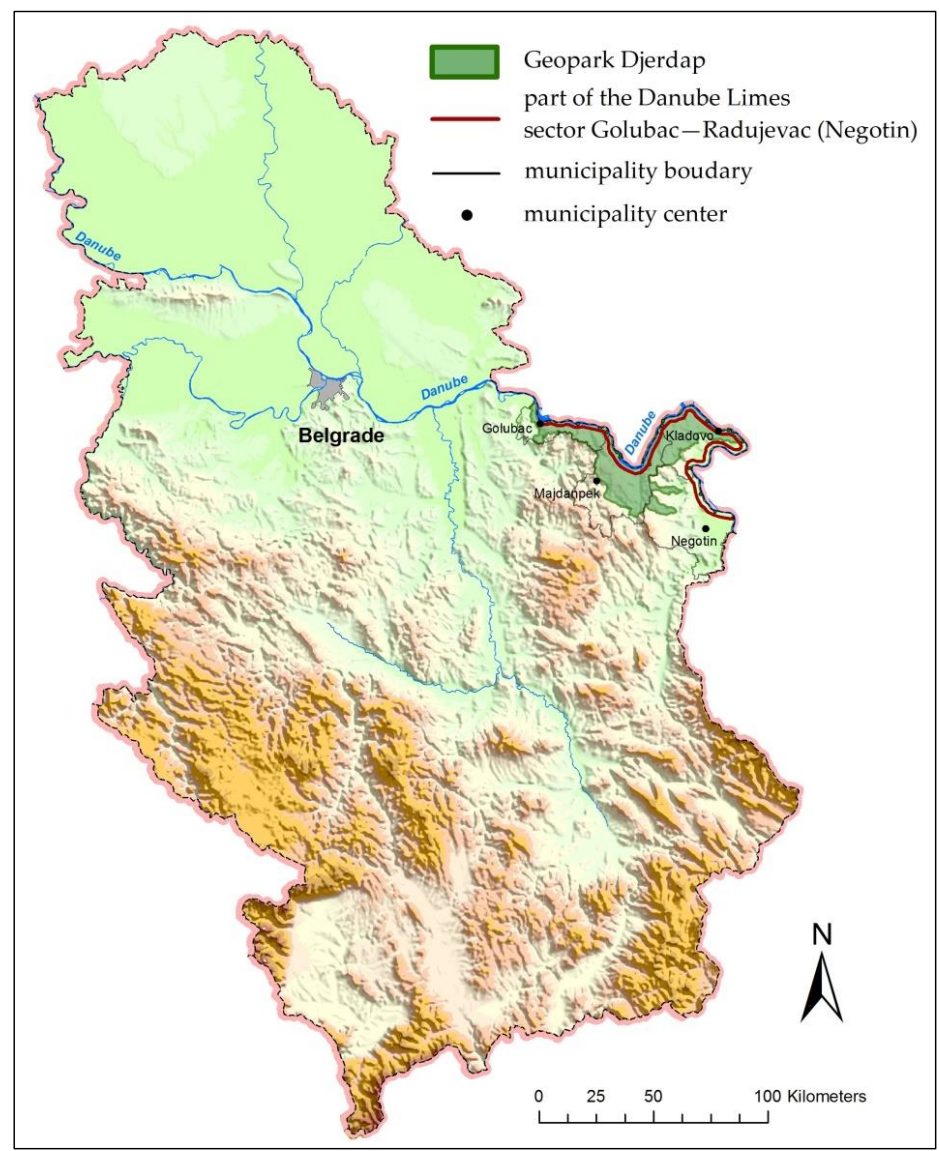

Figure 1. Part of the Danube Limes in Serbia. 
The natural and cultural heritage of the Djerdap Geopark is an integral part of European cultural heritage and the world network of geoparks. Thus, the locations of archaeological sites and fortifications, as part of the common heritage of ancient civilizations, are integrated for preservation and protection within the framework of regional sustainable economic development [18]. In addition to the connection with geoheritage, the importance of the geopark is also connected with archaeological, ecological, historical, and cultural factors $[19,20]$. Numerous studies show that different regions develop their economy and competitiveness in the tourism market using their cultural heritage as a driver of economic regional development [21,22]. However, cultural heritage should not be solely subject to the laws of the economic market. It is a resource of great importance for tourism, but since it is not a commodity in economic terms, it should be used sustainably [23,24].

Part of the Danube Limes in Serbia, the sector from Golubac to Radujevac, as a tourist attraction area in the cultural-historical sense and with a geographically diverse and specific natural wealth, can be commercialized internationally. Its positioning in the domestic and international tourism market requires systematic research, planning, and implementation of sustainable tourism development.

\section{Methodology}

The tourist valorization of the cultural assets of the Danube Limes in Serbia's GolubacRadujevac region, aims at a detailed assessment of their importance for the development of tourism. The evaluation of individual localities and their logic, connecting them in a meaningful thematic unit, as well as determining the necessary actions for their protection and use within the principles of sustainable tourism development, implies cartographic support. Cartographic visualization of the results of the research of tourist valorization contributes to their better identification, understanding of the geospatial connection between the meaning of the locality, and the clear transfer of information.

Starting from the fact that the cultural assets of this sector reflect the history of the area, and that together with the specific and unique natural environment they provide great opportunities for tourism development, it is necessary to assess their value. The assessment of the value of the cultural assets of the Danube Limes in Serbia's GolubacRadujevac region facilitates the planned organization of the methods of connecting them as a whole and including them in the unique tourist product of this destination. Since this whole area is an integral part of the world's cultural heritage "Borders of the Roman Empire", it is necessary to know about the factors that affect the arrangement, preservation, protection, and use of these tourist attractions, as well as active international cooperation in the framework numerous projects. This would increase the values of this nationally and internationally significant area.

The attraction of this heritage is linked to the historic moment of its construction, the cultural identity bond where it is located, and its beauty [25]. The method of managing this heritage is of utmost importance by means of promoting its preservation and protection for present and future generations. Managing cultural heritage represents a development framework that is under the impact of local conditions. However, it is also regulated by a set of international codes, conventions, and charters on cultural heritage management, preservation, and protection. This is particularly true for world heritage areas [5].

Acquiring the knowledge about the historical context, social, economic, and aesthetic values help in diagnosing the present state of tourist potential, quantifying the values against the visitors' perception and visibility of problematic aspects and actions required for resolving the aforementioned. There is no single universally accepted method and fully comprehensive criteria for the valorization of heritage tourism $[5,26]$. The selection of methods for the valorization of sustainable development in tourism should provide a systematic method for the organizing, combining, and valorization of the defined indicators [9]. Under the methodology by Hilary Du Cros [5], tourist valorization of cultural assets in Danube Limes, Serbia can be covered by evaluating 29 indicators within the tourism and cultural assets management sector. A set of indicators defined under this methodology refers to 
cultural, societal, economic, institutional, and environmental dimensions of sustainability [27]. This was aimed at achieving a comprehensive identification of this area's tourist potential. The following questions need to be answered: "which are the most appropriate cultural heritage places for the development of tourism?" and "what is the best way to manage those heritage places for sustainability?" [7] (p. 166). The application of this model facilitates comprehending the relationship of this destination's localities regarding their tourist attractiveness, commercial expectations, social value, and method of management, protection, and preservation. It is impossible to discuss cultural heritage tourism planning without mentioning cultural heritage management [7] (p. 166). Tourism development and cultural heritage management require compromises, which are hard to attain. In that regard, selecting a valorization method is of utmost importance. The application of Hilary Du Cros methodology covering a broad set of indicators provides for a more realistic overview and identification of heritage sites with the best tourist potential and indicates a selection of priorities in the process of managing the heritage of this destination [5].

\subsection{Tourist Valorization}

The tourist valorization of the cultural assets of the Danube Limes in Serbia's GolubacRadujevac region in this paper was carried out according to the model by Hilary Du Cros $[5,6]$. Research and evaluation of sub-indicators were conducted by the authors of this paper in 2020. The methodological procedure includes relevant indicators necessary for compiling the survey, which was conducted with the involvement of experts specialized in research on the subject matter in this field. A questionnaire was compiled, and indicators were evaluated by 30 experts from relevant fields for this research (five geographers, five tourismologists, five historians, five archaeologists, five geodetic officers, and five tourist guides). The selection of respondents was conditioned only by their professional research in this area. This strived for maximum objectivity in the answers to obtain the most realistic assessment. Based on their expert evaluations of indicators within the questionnaire, data processing and analysis were performed by the authors of the paper. By evaluating cultural assets (individually and as a whole), an assessment of the factual situation was made, and guidelines were given, including measures that should be taken for the further development of tourism. Sub-indicators and methods of their evaluation are systematized in a table, for easier overview (Tables 2 and 3).

Tourist valorization, according to the Hilary Du Cros model, includes two groups of sub-indicators that are evaluated:

I. Tourism sector (valorization covers: 1. market attractiveness of cultural assets; and 2. factors of importance in designing a tourism product); and

II. Cultural assets' management sector (valorizing: 1. cultural significance; and 2. robustness) $[5-7,28,29]$.

Assessment was performed for each indicator separately, with a selected descriptive scale that is ranked concerning the degree of assessment. The total score for each sector was then calculated. The grading of the scale was not unified for all locations. Indicators were evaluated, depending on the character of the description, from 0-5: (17 indicators), 0-4 (4 indicators), 0-3 (3 indicators), and from 0-2 (2 indicators) (Tables 2 and 3).

After the individual evaluation of sub-indicators, ratings were summarized by sectors. The cumulative scores of each sector are represented by a matrix, which is formed by 9 cells marked with $\mathrm{M}(i, j)$. The sub-indicators of the tourism sector $(i)$ are: 1 . market attractiveness of cultural assets and factors of importance in designing a tourism product), and the sub-indicators of the cultural assets' management sector are: 1. cultural significance; and 2. robustness. Both sub-indicators were evaluated according to cumulative values and given in three categories: 1-0-20 (low value); $\mathrm{m}-20-40$ (medium) and $\mathrm{h}-40-60$ (high value) (Table 4) $[5-7,28,29]$. The position in the matrix identifies cultural assets against their potentials. Each cultural asset is valorized against the values of indicators/sub-indicators, against market attractiveness, tourist attractiveness, cultural significance and robustness. The localities with high robustness values are appropriate for tourism attractiveness (pri- 
mary tourism attractions). The medium values of tourism attractiveness and market attractiveness, along with medium to high values of robustness categorize the localities as secondary tourism attractions. The localities with low values of robustness require the introduction of protection and preservation measures, while the ones with low values of attractiveness and tourist attraction should be protected as the research potentials $[5,7]$.

Table 2. Sub-indicators for tourism sector according to the Hilary Du Cros model [5-7,28,29].

\begin{tabular}{|c|c|c|c|c|c|c|c|}
\hline \multicolumn{8}{|c|}{ I-Tourism Sector } \\
\hline & Rating & 0 & 1 & 2 & 3 & 4 & 5 \\
\hline \multirow{9}{*}{ 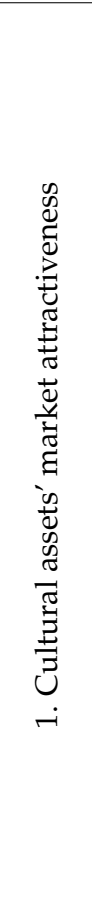 } & Ambiance & Weak & Weak & Appropriate & Appropriate & Very good & Excellent \\
\hline & $\begin{array}{l}\text { Known outside the } \\
\text { local territory }\end{array}$ & No & No & Partially & Partially & Very good & Very good \\
\hline & $\begin{array}{c}\text { Significant national } \\
\text { symbol }\end{array}$ & No & $\begin{array}{l}\text { No certain } \\
\text { potential }\end{array}$ & $\begin{array}{c}\text { Has certain } \\
\text { potential }\end{array}$ & $\begin{array}{l}\text { Has certain } \\
\text { potential }\end{array}$ & Yes & Yes \\
\hline & Evocative location & No & $\begin{array}{c}\text { Has certain } \\
\text { potential }\end{array}$ & $\begin{array}{l}\text { Has certain } \\
\text { potential }\end{array}$ & $\begin{array}{l}\text { Has certain } \\
\text { potential }\end{array}$ & Yes & Yes \\
\hline & $\begin{array}{l}\text { Has certain properties } \\
\text { that differentiate it } \\
\text { from neighboring } \\
\text { cultural assets }\end{array}$ & Poor & Poor & Appropriate & Appropriate & Good & Excellent \\
\hline & $\begin{array}{c}\text { Attractive for special } \\
\text { purposes }\end{array}$ & No & $\begin{array}{l}\text { Has certain } \\
\text { potential }\end{array}$ & $\begin{array}{l}\text { Has certain } \\
\text { potential }\end{array}$ & $\begin{array}{l}\text { Has certain } \\
\text { potential }\end{array}$ & Yes & Yes \\
\hline & $\begin{array}{l}\text { Complementary to } \\
\text { other tourism } \\
\text { products }\end{array}$ & No & $\begin{array}{l}\text { Has certain } \\
\text { potential }\end{array}$ & $\begin{array}{l}\text { Has certain } \\
\text { potential }\end{array}$ & $\begin{array}{l}\text { Has certain } \\
\text { potential }\end{array}$ & Yes & Yes \\
\hline & $\begin{array}{c}\text { Tourism activity } \\
\text { within the region }\end{array}$ & Low & Low & $\begin{array}{l}\text { Has certain } \\
\text { potential }\end{array}$ & $\begin{array}{l}\text { Has certain } \\
\text { potential }\end{array}$ & High & High \\
\hline & $\begin{array}{l}\text { Destination linked to } \\
\text { the cultural heritage }\end{array}$ & No & No & $\begin{array}{c}\text { Has certain } \\
\text { potential }\end{array}$ & $\begin{array}{l}\text { Has certain } \\
\text { potential }\end{array}$ & High & High \\
\hline \multirow{4}{*}{ 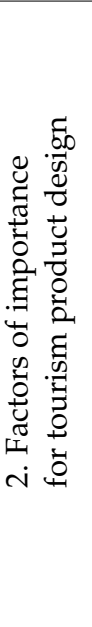 } & $\begin{array}{c}\text { Access to } \\
\text { cultural asset }\end{array}$ & Prohibited & $\begin{array}{l}\text { Limited } \\
\text { access }\end{array}$ & $\begin{array}{l}\text { Limited } \\
\text { access }\end{array}$ & $\begin{array}{c}\text { Access } \\
\text { permitted } \\
\text { to all } \\
\text { elements } \\
\text { of cultural } \\
\text { asset }\end{array}$ & $\begin{array}{c}\text { Access } \\
\text { permitted } \\
\text { to all } \\
\text { elements } \\
\text { of cultural } \\
\text { asset }\end{array}$ & / \\
\hline & $\begin{array}{l}\text { Access from the } \\
\text { settlement to } \\
\text { cultural asset }\end{array}$ & $\begin{array}{l}\text { Very } \\
\text { remote/ } \\
\text { difficult } \\
\text { access }\end{array}$ & $\begin{array}{l}\text { Facilitated } \\
\text { access }\end{array}$ & $\begin{array}{l}\text { Facilitated } \\
\text { access }\end{array}$ & $\begin{array}{l}\text { Excellent } \\
\text { access }\end{array}$ & / & / \\
\hline & $\begin{array}{l}\text { Vicinity of other } \\
\text { cultural attractions }\end{array}$ & $\begin{array}{l}\text { Very } \\
\text { remote/ } \\
\text { difficult }\end{array}$ & $\begin{array}{l}\text { Facilitated } \\
\text { access }\end{array}$ & $\begin{array}{l}\text { Facilitated } \\
\text { access }\end{array}$ & $\begin{array}{l}\text { Distance may } \\
\text { be easily and } \\
\text { fast crossed } \\
\text { on foot }\end{array}$ & / & / \\
\hline & Auxiliary content & Weak & Appropriate & Appropriate & Good & Good & Excellent \\
\hline
\end{tabular}


Table 3. Sub-indicators for the cultural assets management sector according to Hilary Du Cros model $[5-7,28,29]$

\begin{tabular}{|c|c|c|c|c|c|c|c|}
\hline \multicolumn{8}{|c|}{ II-Cultural Assets Management Sector } \\
\hline & Rating & 0 & 1 & 2 & 3 & 4 & 5 \\
\hline \multirow{7}{*}{ 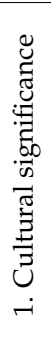 } & Aesthetic value & Low & Medium & High & I & I & I \\
\hline & Historical value & Low & Medium & High & / & / & / \\
\hline & Educational value & Low & Medium & High & / & / & / \\
\hline & Social value & Low & Medium & High & / & I & / \\
\hline & Scientific-research value & Low & Medium & High & / & / & / \\
\hline & $\begin{array}{l}\text { Cultural asset rarity } \\
\text { (local, regional, national) }\end{array}$ & $\begin{array}{l}\text { Common } \\
\text { typical cultural } \\
\text { assets }\end{array}$ & $\begin{array}{l}\text { Less common } \\
\text { typical cultural } \\
\text { assets }\end{array}$ & $\begin{array}{l}\text { Rare typical } \\
\text { cultural assets }\end{array}$ & $\begin{array}{l}\text { Unique typical } \\
\text { cultural assets }\end{array}$ & / & / \\
\hline & $\begin{array}{l}\text { Representativeness } \\
\text { for the destination }\end{array}$ & Weak & Weak & Good & Good & Excellent & / \\
\hline \multirow{11}{*}{ 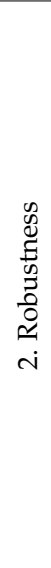 } & Cultural asset sensitivity & Non-sensitive & Significant & Significant & Major & Major & l \\
\hline & State of reparation & Poor & Partial & Good & Good & Excellent & / \\
\hline & $\begin{array}{l}\text { Existence of the cultural asset } \\
\text { management plan }\end{array}$ & None & $\begin{array}{l}\text { Under } \\
\text { preparation }\end{array}$ & $\begin{array}{l}\text { Under } \\
\text { preparation }\end{array}$ & $\begin{array}{l}\text { Under } \\
\text { preparation }\end{array}$ & $\begin{array}{l}\text { Under } \\
\text { preparation }\end{array}$ & Existing \\
\hline & $\begin{array}{l}\text { Regular monitoring and } \\
\text { maintenance }\end{array}$ & Weak & Partial & Partial & Good & Good & Excellent \\
\hline & $\begin{array}{l}\text { Potential for investment and } \\
\text { consultation of stakeholders }\end{array}$ & Weak & Appropriate & Appropriate & Good & Good & Excellent \\
\hline & \multicolumn{7}{|c|}{ The potential of high visitation impact on: } \\
\hline & $\begin{array}{l}\text { Cultural asset } \\
\text { Physical state }\end{array}$ & Low & Medium & Medium & Medium & High & High \\
\hline & $\begin{array}{l}\text { Lifestyle and cultural tradition } \\
\text { of the local community }\end{array}$ & Low & Medium & Medium & Medium & High & High \\
\hline & \multicolumn{7}{|c|}{ Possibility for a modification as a part of the product development to yield a negative impact on: } \\
\hline & Cultural asset Physical state & Low & Medium & Medium & Medium & High & High \\
\hline & $\begin{array}{l}\text { Lifestyle and cultural tradition } \\
\text { of the local community }\end{array}$ & Low & Medium & Medium & Medium & High & High \\
\hline
\end{tabular}

Table 4. Touristic valorization according to the Hilary Du Cros model [5-7,28,29].

\begin{tabular}{cccc}
\hline & Tourism Sector $(\boldsymbol{i})$ & & $\begin{array}{c}\text { Cultural Assets' } \\
\text { Management }(j)\end{array}$ \\
\hline $\mathbf{1 - 0 - 2 0}$ & $\mathbf{m}-\mathbf{2 1 - 4 0}$ & $\mathbf{h}-\mathbf{4 1 - 6 0}$ & $\mathrm{h}-41-60$ \\
$\mathrm{M}(\mathrm{l}, \mathrm{h})$ & $\mathrm{M}(\mathrm{m}, \mathrm{h})$ & $\mathrm{M}(\mathrm{h}, \mathrm{h})$ & $\mathrm{m}-21-40$ \\
$\mathrm{M}(\mathrm{l}, \mathrm{m})$ & $\mathrm{M}(\mathrm{m}, \mathrm{m})$ & $\mathrm{M}(\mathrm{h}, \mathrm{m})$ & $\mathrm{l}-0-20$ \\
$\mathrm{M}(\mathrm{l}, \mathrm{l})$ & $\mathrm{M}(\mathrm{m}, \mathrm{l})$ & $\mathrm{M}(\mathrm{h}, \mathrm{l})$ & \\
\hline
\end{tabular}

The cells in the matrix $\mathrm{M}(i, j)$ are defined as follows:

- $\quad \mathrm{M}(\mathrm{l}, \mathrm{h})$ - the low value of sub-indicators of the tourism sector, the high value of sub-indicators of cultural assets' management.

- $\quad \mathrm{M}(\mathrm{m}, \mathrm{h})$ - the medium value of sub-indicators of the tourism sector, the high value of sub-indicators of cultural assets' management.

- $\quad \mathrm{M}(\mathrm{h}, \mathrm{h})$ - high value of sub-indicators of the tourism sector, the high value of subindicators of cultural assets' management.

- $\quad \mathrm{M}(\mathrm{l}, \mathrm{m})$ - the low value of the sub-indicator of the tourism sector, medium value of the sub-indicator of cultural assets' management.

- $\quad \mathrm{M}(\mathrm{m}, \mathrm{m})$ - the medium value of tourism sector sub-indicators, medium value of cultural assets' management sub-indicators.

- $\quad \mathrm{M}(\mathrm{h}, \mathrm{m})$ - high value of sub-indicators of the tourism sector, the medium value of sub-indicators of cultural assets' management.

- $\quad \mathrm{M}(\mathrm{l}, \mathrm{l})$ - the low value of sub-indicators of the tourism sector, low value of subindicators of cultural assets' management.

- $\quad \mathrm{M}(\mathrm{m}, \mathrm{l})$ - the medium value of the sub-indicator of the tourism sector, the low value of the sub-indicator of cultural assets' management.

- $\quad \mathrm{M}(\mathrm{h}, \mathrm{l})$ - high value of sub-indicators of the tourism sector, low value of sub-indicators of cultural assets' management $[5-7,28,29]$. 
In the further procedure, summarized and tabulated systematized data by sectors are graphically represented by a square matrix, for the sake of visually clearer and more concise presentation of information. Concerning the values of aggregate assessments for each prominent property, the matrix graphically indicates their position on the $x$-axis sub-indicators of the tourism sector $(i)$, and on the $y$-axis sub-indicators of cultural property management.

Visual systematization of data for the sake of clear tabular presentation has been switched from numerical to graphical and symbolic presentation. Visually, the signs and colors show the estimates of the values of the sub-indicators of individual localities, and indirectly, the average was obtained visually based on the set of marked colors.

\subsection{Cartographic Visualization}

Visualization of localities, tourist assets of the Danube Limes in Serbia's GolubacRadujevac region, i.e., the obtained values of the research results, was performed with the software suite ArcGIS, version 10.3, by the ESRI company from the USA. The software environment and geospatial data, which were used as a basis, are part of the production process at the Military Geographical Institute in Belgrade. The positioning of the archaeological sites, the border of the Djerdap National Park, and the border of the Djerdap Geopark were performed based on a graphic file and descriptive data from the available literature. The basic and thematic content on all maps is presented by the same selected methods (hypsometric method for displaying relief, sign method for displaying thematic content). A separate map was made for each group of sub-indicators: 1. Assessment of the market attractiveness of cultural goods; 2. Assessment of factors of importance in designing a tourist product; 3. Assessment of cultural significance; and 4. Assessment of robustness. The same symbol mark (circle) was used for easier comparison of sub-indicators on all maps. The size of the circle (sign scalar) is determined concerning the value of the indicator by the functional discrete scale given in the map key. The discrete scale of values sought to show the range of values of grades within a particular group-the category of sub-indicators-more accurately. This did not disturb the basic categorization of the sub-indicator of tourist valorization; instead, it presented the values in more detail. The color of the sign was intended to achieve clarity and visibility of the range of individual localities. Better perception of the tourist valorization of the presented cultural assets was enabled by translating the geodata: text $\rightarrow$ table $\rightarrow$ map.

\section{Research Results}

Applying the Hilary Du Cros model in this research, the possibility of obtaining a realistic basis for tourism development planning and cultural heritage management in this area is considered. A large number of factors ( $\sum 29$ within 4 groups of sub-indicators) that were taken during the valuation of 19 cultural assets of the Danube Limes, allows a detailed assessment of their tourist value. During the analysis, the unification of key factors for all locations was carried out, and within that, and based on expert assessment, the selection of their significance for certain localities was performed, which is also cartographically presented (Figures 2-5).

I-1 The assessment of tourist value (market attractiveness) was made based on 9 indicators evaluated with a rating of $0-5$ (Table 5).

- Ambiance value. All 19 localities of this sector were rated with an average grade of 3. However, as five localities along this destination are submerged, their exclusion gives an average rating of 4 . Cuppae, Roman Road, Hajduk Mill, Tabula Traiana, Diana-Zanes, and Pontes represent extremely important and attractive sites within unique, cultural, and natural complexes, and have a rating of 5 . Better regulation of all sites on the banks of the Danube is necessary to increase the general impression and value of the destination.

- Known outside the local area. Cultural assets: Cuppae, Roman Road, Tabula Traiana, Diana-Zanes, and Pontes were rated 5. Other sites along the Danube Limes sector are not known outside the local area and are rated $0-1$. The average score of all indicators 
is 2 . The regulation and promotion of all, especially 14 sites with a score of $0-1$, must be more efficient and included in the overall modern tourist offer of this area.

- An important national symbol. The significance of all sites of the Danube Limes in Serbia derives from its geostrategic position during all historical epochs. The score for five localities is between 4 and 5 , and for the other 14 localities, it is 0 , which is a concerning fact. Historically, the sites and their significance concerning the events in this area are extremely important cultural monuments. The entire cultural destination is an important national symbol, and as such must be promoted, especially through the education of the population.

- An evocative place. The historical context and the specific geographical area where these cultural assets originated speak of great evocative potential. The number of facts, stories, and legends related to fortifications, roads, and their role of civilizational significance, provides great opportunities for attractive and quality interpretation. The evaluation of evocativeness is 4 .

- Differentiation from the surrounding cultural assets. Roman fortifications represent specific works of Roman civil engineering, which are the attraction of this part of the Limes. However, the localities differ amongst themselves in the obtained assessment under this evaluation. Within the locality, the following destinations are distinguished: Cuppae, Roman Road, Tabula Traiana, Diana-Zanes, and Pontes and are rated 5. Considering its importance and the location itself, these assets have certain characteristics that differentiate them from the surrounding cultural assets. Localities: Konopište, Egeta, and Mora Vagei were rated 3, and the remaining 11 localities received a value of 0 ( 5 of which are submerged). The difference in assessments is conditioned not only by the size and significance of the fortifications during the Roman Empire but also by their isolated position and the importance of revitalization concerning other localities in this area. The average rating is 2 . Revitalization of these fortifications and inclusion in the tourist offer would contribute to its diversity and, thus, the completion of the content.

- The attraction for special purposes. The characteristics of the locations of cultural assets have conditioned the possibility of using them for various purposes. Cultural, educational, sports-leisure, etc. events are just some of the activities that could be organized to increase the current extremely low average score of 1 (except for Cuppae, Roman Road, Tabula Traiana, Diana-Zanes, and Pontes, which have an average score of 4).

- Complementary with other cultural assets. All 19 localities of this sector were rated with an average grade of 4 . Although there are predispositions for greater complementarity with other cultural assets within the development of cultural, event, business, nautical, etc. forms of tourism, these conditions are yet to be exploited. The Roman sites of the Danube Limes, due to their attractions and values, should be used more meaningfully. This especially refers to the fact that part of the site belongs to the Djerdap National Park and the Djerdap Geopark, as well as that they are part of the cultural route "Fortress on the Danube", "Road of Roman Emperors" and "Danube Wine Road" and others. The intertwining of several routes and protected areas provides an opportunity for these cultural assets to be connected, based on cultural-historical ties and to increase their value.

- Tourist activity in the region. The tourist activity of this area is growing, "but the level of tourist organization is relatively weak, due to the lack of clear leadership in the development of tourism at the destination level" [30] (p. 136). The greatest contributors to the tourist activity of this area are Cuppae, Roman Road, Tabula Traiana, Diana-Zanes, and Pontes (grade 5). The other 10 localities, due to lower attendance, have lower values of indicators (rating of 3, excluding 5 submerged localities). "The lack of adequate tourism organization in this area reduces the value of indicators, and to improve the situation, it is necessary to connect the tourism and cultural sector, as well as public and private entrepreneurs" [30] (p. 136). 
- A destination related to culture or heritage. Essentially, the tourist activity of this area is based on cultural and historical heritage. All fortifications are categorized as cultural monuments of exceptional national and international importance. The average rating is 5 .

By evaluating the indicators and determining the assessment of the tourist value (market attractiveness) of each cultural asset, their cumulative assessments were obtained, which range from 15-40. Based on the previously determined scale: 0-20 low attractiveness, 20-40 medium attractiveness, and 40-60 high attractiveness, it is concluded that cultural assets belong to the categories of low and medium attractiveness. Localities submerged due to the construction of the dam: Cantabaza, Ad Scrofulas, Roman Road and Imperial Inscriptions, Smorna, and Campsa have the lowest values of ratings, which affects the cumulative values of individual indicators. Therefore, they have been presented both in summary and separately through the previous analysis.

Table 5. Cultural assets' tourist value (market attractiveness) rating.

\begin{tabular}{|c|c|c|c|c|c|c|c|c|c|c|c|c|c|c|c|c|c|c|c|}
\hline Market Value Rating & & & & & & $\stackrel{\infty}{0}$ & & & & & $\cong$ & & & & & & & & \\
\hline $\begin{array}{r}\Delta 5 \\
\Delta 4 \\
\Delta 3 \\
2 \\
\Delta 1 \\
\triangle 0\end{array}$ & 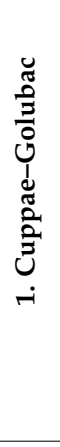 & 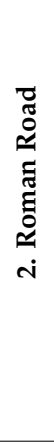 & 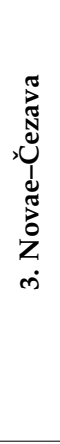 & 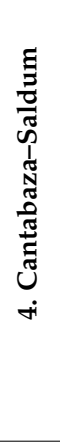 & 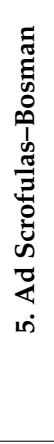 & 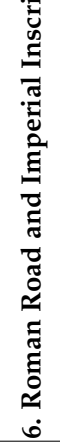 & 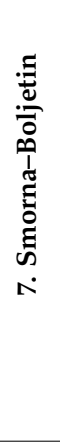 & 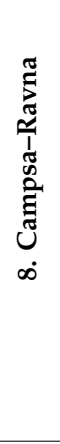 & 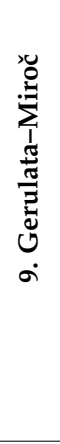 & 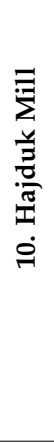 & 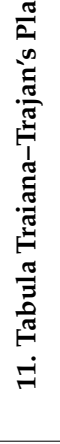 & 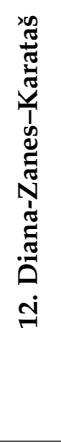 & 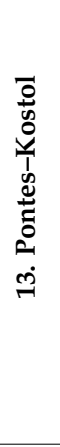 & 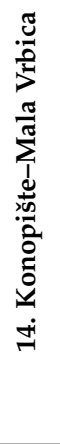 & 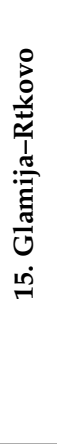 & 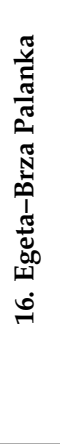 & 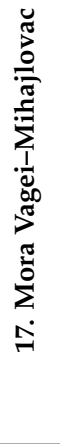 & 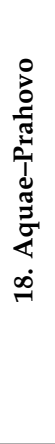 & 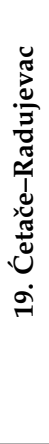 \\
\hline Ambiance & $\Delta$ & $\Delta$ & $\Delta$ & $\Delta$ & $\Delta$ & $\Delta$ & $\Delta$ & $\Delta$ & $\Delta$ & $\Delta$ & $\Delta$ & $\Delta$ & $\Delta$ & $\Delta$ & $\Delta$ & $\Delta$ & $\Delta$ & $\Delta$ & $\Delta$ \\
\hline $\begin{array}{l}\text { Known outside the } \\
\text { local territory }\end{array}$ & $\Delta$ & $\Delta$ & $\Delta$ & $\Delta$ & $\Delta$ & $\Delta$ & $\Delta$ & $\Delta$ & $\Delta$ & $\Delta$ & $\Delta$ & $\Delta$ & $\Delta$ & $\Delta$ & $\Delta$ & $\Delta$ & $\Delta$ & $\Delta$ & $\Delta$ \\
\hline Significant national symbol & $\Delta$ & $\Delta$ & $\Delta$ & $\Delta$ & $\Delta$ & $\Delta$ & $\Delta$ & $\Delta$ & $\Delta$ & $\Delta$ & $\Delta$ & $\Delta$ & $\Delta$ & $\Delta$ & $\Delta$ & $\Delta$ & $\Delta$ & $\Delta$ & $\Delta$ \\
\hline Evocative location & $\Delta$ & $\Delta$ & $\Delta$ & $\Delta$ & $\Delta$ & $\Delta$ & $\Delta$ & $\Delta$ & $\Delta$ & $\Delta$ & $\Delta$ & $\Delta$ & $\Delta$ & $\Delta$ & $\Delta$ & $\Delta$ & $\Delta$ & $\Delta$ & $\Delta$ \\
\hline $\begin{array}{l}\text { Has certain properties } \\
\text { that differentiate } \\
\text { it from neighboring } \\
\text { cultural assets }\end{array}$ & $\Delta$ & $\Delta$ & $\Delta$ & $\Delta$ & $\Delta$ & $\Delta$ & $\Delta$ & $\Delta$ & $\Delta$ & $\Delta$ & $\Delta$ & $\Delta$ & $\Delta$ & $\Delta$ & $\Delta$ & $\Delta$ & $\Delta$ & $\Delta$ & $\Delta$ \\
\hline $\begin{array}{c}\text { Attractive for } \\
\text { special purposes }\end{array}$ & $\Delta$ & $\Delta$ & $\Delta$ & $\Delta$ & $\Delta$ & $\Delta$ & $\Delta$ & $\Delta$ & $\Delta$ & $\Delta$ & $\Delta$ & $\Delta$ & $\Delta$ & $\Delta$ & $\Delta$ & $\Delta$ & $\Delta$ & $\Delta$ & $\Delta$ \\
\hline $\begin{array}{l}\text { Complementary to other } \\
\text { tourism products }\end{array}$ & $\Delta$ & $\Delta$ & $\Delta$ & $\Delta$ & $\Delta$ & $\Delta$ & $\Delta$ & $\Delta$ & $\Delta$ & $\Delta$ & $\Delta$ & $\Delta$ & $\Delta$ & $\Delta$ & $\Delta$ & $\Delta$ & $\Delta$ & $\Delta$ & $\Delta$ \\
\hline $\begin{array}{c}\text { Tourism activity } \\
\text { within the region }\end{array}$ & $\Delta$ & $\Delta$ & $\Delta$ & $\Delta$ & $\Delta$ & $\Delta$ & $\Delta$ & $\Delta$ & $\Delta$ & $\Delta$ & $\Delta$ & $\Delta$ & $\Delta$ & $\Delta$ & $\Delta$ & $\Delta$ & $\Delta$ & $\Delta$ & $\Delta$ \\
\hline $\begin{array}{l}\text { Destination linked } \\
\text { to the cultural heritage }\end{array}$ & $\Delta$ & $\Delta$ & $\Delta$ & $\Delta$ & $\Delta$ & $\Delta$ & $\Delta$ & $\Delta$ & $\Delta$ & $\Delta$ & $\Delta$ & $\Delta$ & $\Delta$ & $\Delta$ & $\Delta$ & $\Delta$ & $\Delta$ & $\Delta$ & $\Delta$ \\
\hline
\end{tabular}

The following procedure of cartographic visualization adopted the given framework of the scale of values of the tourist valorization sub-indicator. This allowed for a harmonized comparison of indicators. However, in the process of visualization, the range of the scale was broken down and adjusted to the framework of predefined categories of sub-indicators, for a more precise perception of the value. Therefore, the following was obtained:

- Category I 0-20 (low attractiveness), values from Table 5 were obtained, more precisely given within the group and represented by a key on the map in the range of $0-15$;

- Category II 20-40 (medium attractiveness), values from Table 5 were obtained, more precisely given through 3 subgroups and represented by a key on the map in the range 20-24, 25-29, and 30-40 (Figure 2).

By translating the data on the relation text $\rightarrow$ table $\rightarrow$ map, more precise separation and highlighting were achieved, as well as a better visual perception of the range of values 
within the defined categories. This resulted in both comparability and a more precise range value. Values are represented by the sign method, using a functional breakdown scale. The color of the sign emphasizes the clarity of the range of indicators of the phenomenon. The basis of the map on which the thematic content was plotted enabled the location accuracy and the mutual spatial connection of the locations of individual cultural assets.

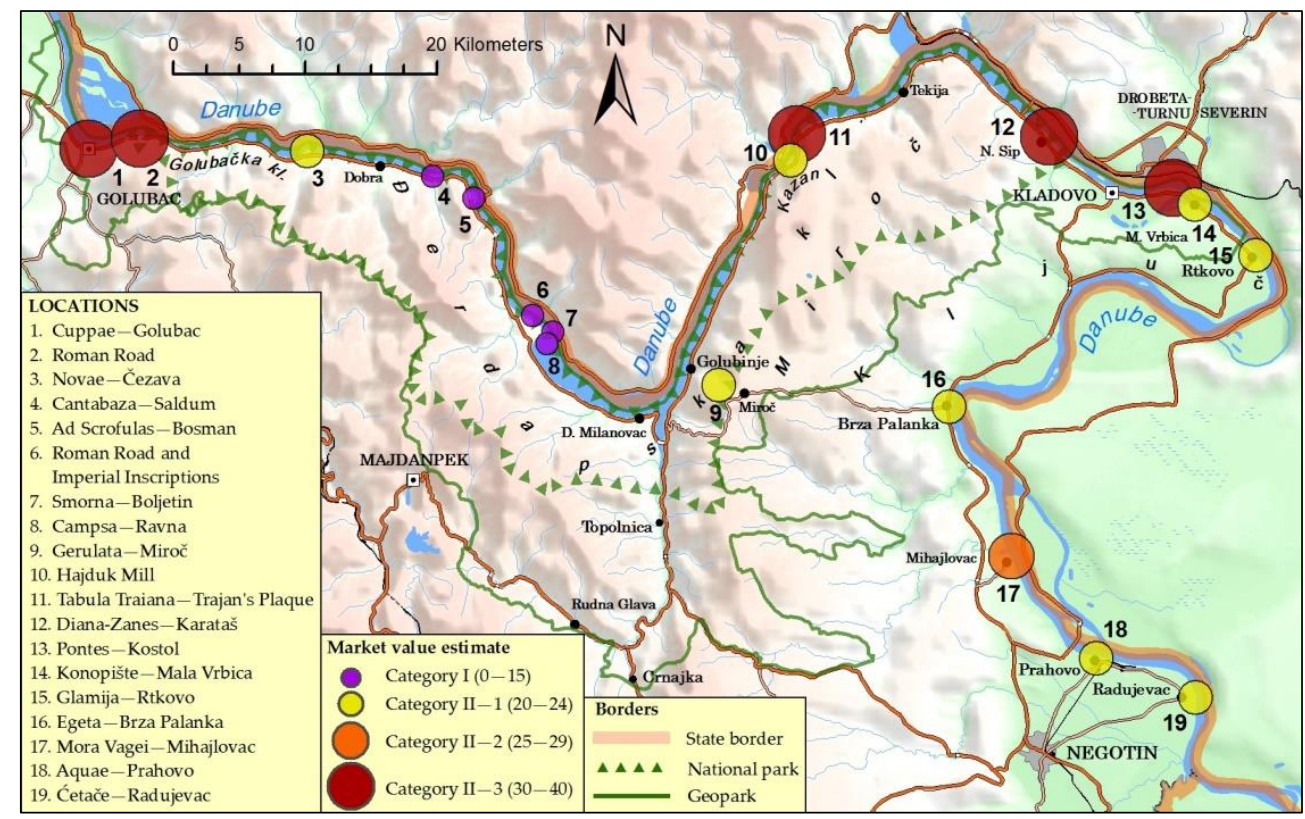

Figure 2. Values of summary market attractiveness of cultural assets.

I-2 The assessment of factors of importance in the design of a tourist product was carried out based on 4 indicators evaluated: ratings 0-4 (indicator I), ratings 0-3 (indicator II and III), ratings 0-5 (indicator IV) (Table 6).

- Access to the cultural asset. Access to Roman sites is not at a satisfactory level. The average accessibility rating is 2 (excluding submerged sites). Access to cultural assets is not well realized, although there are favorable opportunities (except for sites 4-8). The sites are connected to the Danube, so it is possible to provide good access by water. Regional and Local Roads need to be better connected to regional roads and Transport Corridor X. This would significantly improve accessibility.

- Access from the settlement to the cultural asset. The quality of access to Roman sites from the settlement has a value of 2 (facilitated access). Accessibility to localities from settlements must be better organized, especially when greater involvement of the local population in activities related to the development of tourism in this area is planned.

- Vicinity of other cultural attractions. The sites of the Danube Limes, in the region of Golubac-Radujevac, are located in the area of the most attractive cultural and historical destinations in Serbia. Djerdap National Park and Djerdap Geopark, which include part of these sites, contribute to a rating of 2 (in the range of 1-3 according to the given scale of Table 2).

- Auxiliary content. This indicator has very low values for all localities. Resolving this issue is extremely important because the facilities of service activities are necessary content for the existence and improvement of the attractiveness of localities. This includes the construction of appropriate access paths, panoramic stops and rest areas with parking spaces, info-points, panels related to information on sites (location, context, and significance), etc.

By evaluating each indicator and determining the assessment of factors of importance in the design of the tourist product, cumulative assessments at the range of 15-40 were obtained. Based on the previously determined scale: 0-20 low attractiveness, 20-40 medium 
attractiveness, and 40-60 high attractiveness, it may be concluded that cultural assets belong to the categories of low attractiveness. Localities submerged due to the construction of the dam: Cantabaza-Saldum, Ad Scrofulas-Bosman, Roman Road and Imperial Inscriptions, Smorna-Boljetin, and Campsa-Ravna have the lowest values of ratings, which affects the lower cumulative values of individual indicators.

Table 6. Evaluation of factors of importance when designing a tourist product.

\begin{tabular}{|c|c|c|c|c|c|c|c|c|c|c|c|c|c|c|c|c|c|c|c|}
\hline Tourist Product Rating & & & & & & $\stackrel{0}{0}$ & & & & & $\cong$ & & & & & & & & \\
\hline $\begin{array}{r}\Delta 5 \\
\Delta 4 \\
\Delta 3 \\
2 \\
\Delta 1 \\
\Delta 0\end{array}$ & 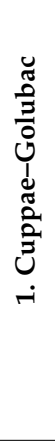 & 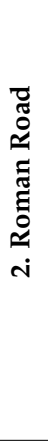 & 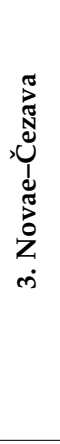 & 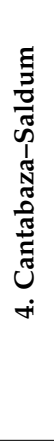 & 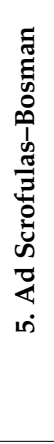 & 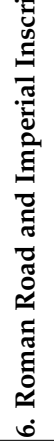 & 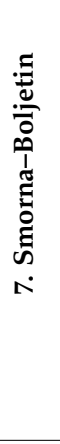 & 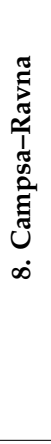 & 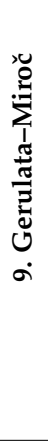 & 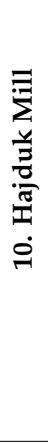 & 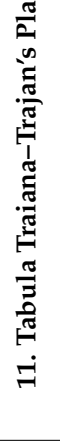 & 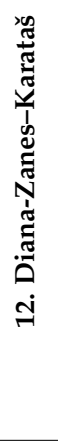 & 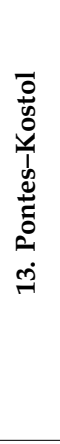 & 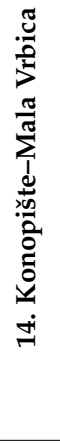 & 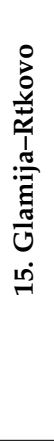 & 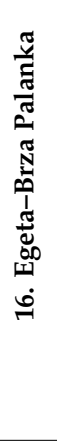 & 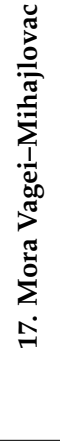 & 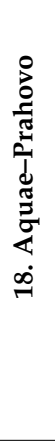 & 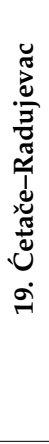 \\
\hline $\begin{array}{l}\text { Access to cultural asset } \\
\text { Access from }\end{array}$ & $\Delta$ & $\Delta$ & $\Delta$ & $\Delta$ & $\Delta$ & $\Delta$ & $\Delta$ & $\Delta$ & $\Delta$ & $\Delta$ & $\Delta$ & $\Delta$ & $\Delta$ & $\Delta$ & $\Delta$ & $\Delta$ & $\Delta$ & $\Delta$ & $\Delta$ \\
\hline $\begin{array}{l}\text { the settlement } \\
\text { to cultural asset }\end{array}$ & $\Delta$ & $\Delta$ & $\Delta$ & $\Delta$ & $\Delta$ & $\Delta$ & $\Delta$ & $\Delta$ & $\Delta$ & $\Delta$ & $\Delta$ & $\Delta$ & $\Delta$ & $\Delta$ & $\Delta$ & $\Delta$ & $\Delta$ & $\Delta$ & $\Delta$ \\
\hline $\begin{array}{l}\text { Vicinity of other } \\
\text { cultural attractions }\end{array}$ & $\Delta$ & $\Delta$ & $\Delta$ & $\Delta$ & $\Delta$ & $\Delta$ & $\Delta$ & $\Delta$ & $\Delta$ & $\Delta$ & $\Delta$ & $\Delta$ & $\Delta$ & $\Delta$ & $\Delta$ & $\Delta$ & $\Delta$ & $\Delta$ & $\Delta$ \\
\hline Auxiliary content & $\Delta$ & $\Delta$ & $\Delta$ & $\Delta$ & $\Delta$ & $\Delta$ & $\Delta$ & $\Delta$ & $\Delta$ & $\Delta$ & $\Delta$ & $\Delta$ & $\Delta$ & $\Delta$ & $\Delta$ & $\Delta$ & $\Delta$ & $\Delta$ & $\Delta$ \\
\hline
\end{tabular}

The cartographically presented values of the estimates of factors of importance in the design of a tourist product range within the defined scale of tourist valorization of subindicators. By further comparing indicators, the cumulative values were visualized, broken down within the I category 0-20 (low attractiveness) into subgroups in the range of $0-5$ and 6-10. This provides a clear and more accurate presentation of the range of summarized values of scores within the group according to location characteristics (Table 6, Figure 3).

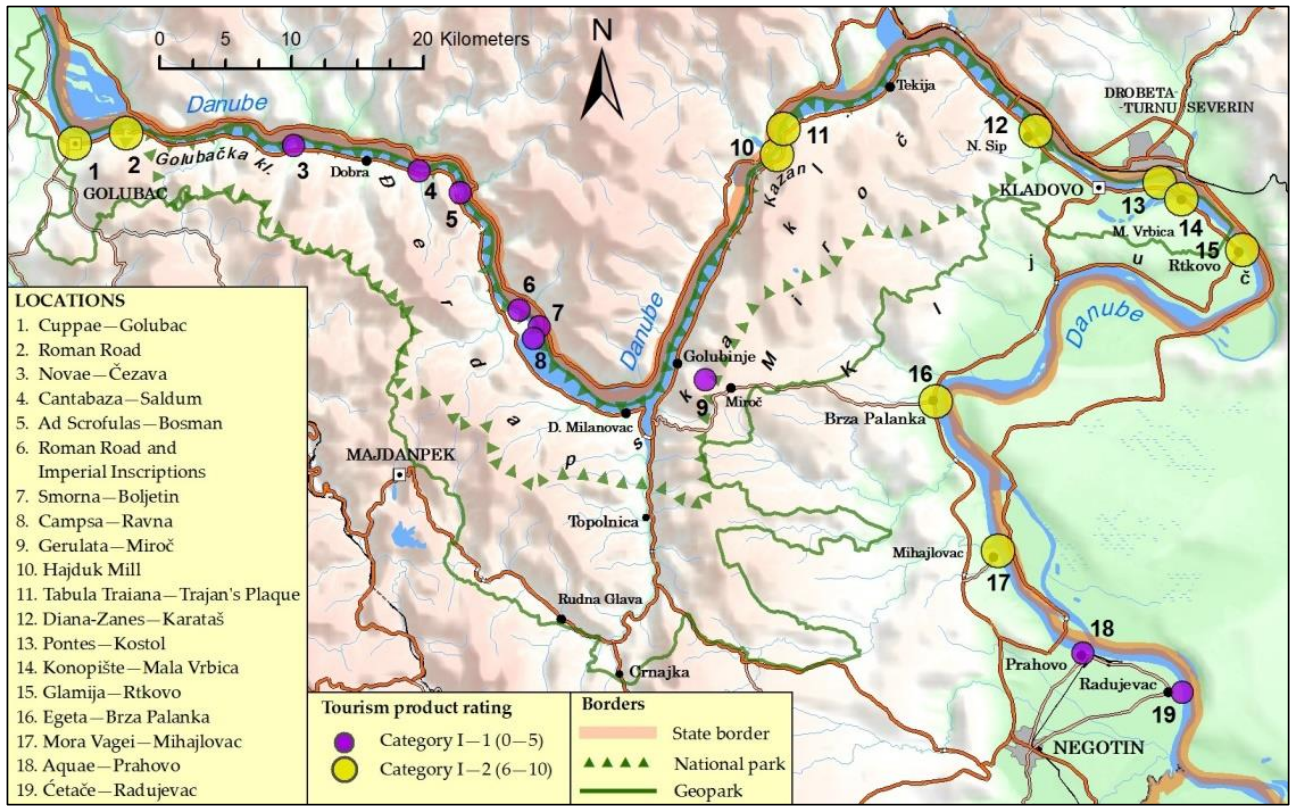

Figure 3. Values of summary estimates of factors of importance in the design of a tourist product. 
Data translation text $\rightarrow$ table $\rightarrow$ map and georeferencing, in an obvious way, indicate the importance of the relationship between locations and values of indicators. As with the previous map (Figure 2), the method of signs was used (the center of the sign is placed in the location center) and color, which provides clarity. Comparability was achieved by the basic content of the map (relief, hydrography, settlements, borders), due to the orientation of the spatial distribution of the mapped localities.

II-1 The assessment of cultural significance was made based on 6 indicators evaluated by ratings: 0-3 (1 indicator), 0-4 (1 indicator), 0-2 (aesthetic, historical, social, scientific-research value) (Table 7).

- Aesthetic value. Roman sites are cultural assets of exceptional national and international importance. Out of 19 localities, five are submerged, so they are evaluated with a rating of 0 . Other localities, in addition to significant construction value and the environment in which they are located, have ratings of 1 and 2. Rating 2 (high aesthetic value) was assigned to Cuppae, Tabula Traiana, Diana-Zanes, Pontes and Mora Vagei. The remaining nine localities have a rating of 1 (medium aesthetic value), mainly due to their physical condition. Material investments in their renovation and professional preservation would increase their aesthetic value.

- Historical value. All localities were rated the highest-2 (high historical value). The value derives from the historical and military-strategic significance of the Danube Limes, nationally and internationally. The historical significance of the borders of the Roman Empire on the Danube is seen not only from the aspect of national history but also from the history of the Balkans, Europe, and beyond. Roman fortifications and roads, depending on their strategic position, had individual different meanings during important historical events, which influenced their size. However, their total value derives from their connection to a single unit.

- Educational value. The historical, geographical, military, archaeological, architectural and construction significance determined the high educational value of these sites (rating 2-high educational value). Educational contents should include not only performances of individual fortifications but all facilities as a complex.

- Social value. The localities of this part of the Limes have different tourist visitation rates and are used differently by the local population. The average rating is 1 (medium). Therefore, it is necessary to involve the local population in the organization of various forms of gathering and socializing with visitors. Concerning the locations and arrangement of Roman fortifications, it is necessary to increase the attractiveness of various traditional contents and thus increase the attendance of tourists.

- Scientific-research value. Historical events in this area and numerous archaeological sites yield scientific research potential. Due to that, the scientific-research value was rated high (rate 2 -high value). Given that most sites are poorly researched, the existence of a vast number of interested experts, as well as international cooperation projects for research and conservation of this area, the scientific research value is extremely high.

- The rarity of the cultural asset at the destination or in the region. All sites of the Danube Limes in Serbia represent unique cultural assets. Specifics of the locality: Cuppae, Roman Road, Tabula Traiana, Diana-Zanes, Pontes, Egeta, and Mora Vagei classify them as unique cultural assets. Other sites have a score of 1 and are treated as less common cultural assets. The average rating of all 19 localities is 3 .

- Representativeness for the destination. Archaeological heritage in the area of the Danube Limes in Serbia is an integral part of the world heritage "Borders of the Roman Empire". Within national significance, belonging to the Djerdap National Park and the Djerdap Geopark, and as cultural monuments under the protection of UNESCO, the sites in the Golubac-Radujevac region are the representative facilities. The average score for the site is 4 ( 5 submerged sites are excluded). 
Table 7. Assessment of cultural significance.

\begin{tabular}{|c|c|c|c|c|c|c|c|c|c|c|c|c|c|c|c|c|c|c|c|}
\hline $\begin{array}{c}\text { Assessment of } \\
\text { Cultural Significance }\end{array}$ & & & & & & $\stackrel{n}{\stackrel{0}{\tilde{a}}}$ & & & & & $\stackrel{\Xi}{\Xi}$ & & & & & & & & \\
\hline $\begin{array}{l}\Delta 5 \\
\Delta 4 \\
\Delta 3 \\
2 \\
\Delta 1 \\
\triangle 0\end{array}$ & 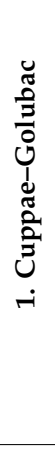 & 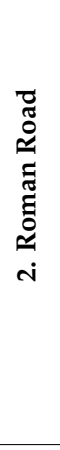 & 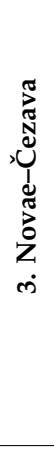 & 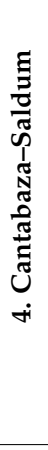 & 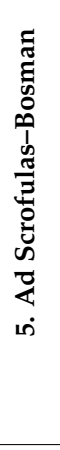 & 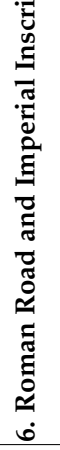 & 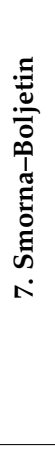 & 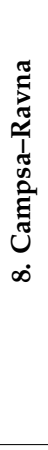 & 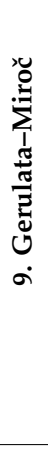 & 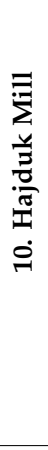 & 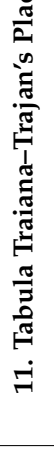 & 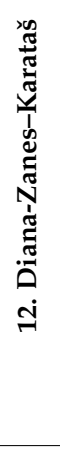 & 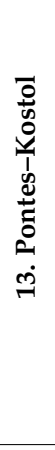 & 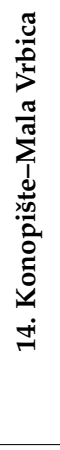 & 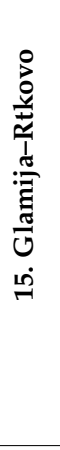 & 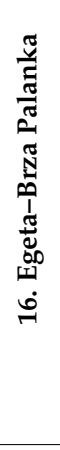 & 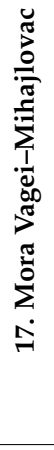 & 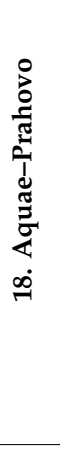 & 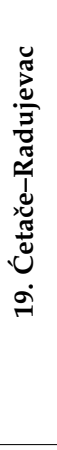 \\
\hline $\begin{array}{l}\text { Cultural asset rarity } \\
\text { (local, regional, national) } \\
\text { Representativeness } \\
\text { for the destination }\end{array}$ & $\Delta$ & $\Delta$ & $\Delta$ & $\Delta$ & $\Delta$ & $\Delta$ & $\Delta$ & $\Delta$ & $\Delta$ & $\Delta$ & $\Delta$ & $\Delta$ & $\Delta$ & $\Delta$ & $\Delta$ & $\Delta$ & $\Delta$ & $\Delta$ & $\Delta$ \\
\hline \multicolumn{20}{|l|}{$\begin{array}{l}\Delta 2 \text { high } \\
\Delta 1 \text { medium } \\
\Delta 0 \text { low }\end{array}$} \\
\hline Aesthetic value & $\Delta$ & $\Delta$ & $\Delta$ & $\Delta$ & $\Delta$ & $\Delta$ & $\Delta$ & $\Delta$ & $\Delta$ & $\Delta$ & $\Delta$ & $\Delta$ & $\Delta$ & $\Delta$ & $\Delta$ & $\Delta$ & $\Delta$ & $\Delta$ & $\Delta$ \\
\hline Historical value & $\Delta$ & $\Delta$ & $\Delta$ & $\Delta$ & $\Delta$ & $\Delta$ & $\Delta$ & $\Delta$ & $\Delta$ & $\Delta$ & $\Delta$ & $\Delta$ & $\Delta$ & $\Delta$ & $\Delta$ & $\Delta$ & $\Delta$ & $\Delta$ & $\Delta$ \\
\hline Educational value & $\Delta$ & $\Delta$ & $\Delta$ & $\Delta$ & $\Delta$ & $\Delta$ & $\Delta$ & $\Delta$ & $\Delta$ & $\Delta$ & $\Delta$ & $\Delta$ & $\Delta$ & $\Delta$ & $\Delta$ & $\Delta$ & $\Delta$ & $\Delta$ & $\Delta$ \\
\hline Social value & $\Delta$ & $\Delta$ & $\Delta$ & $\Delta$ & $\Delta$ & $\Delta$ & $\Delta$ & $\Delta$ & $\Delta$ & $\Delta$ & $\Delta$ & $\Delta$ & $\Delta$ & $\Delta$ & $\Delta$ & $\Delta$ & $\Delta$ & $\Delta$ & $\Delta$ \\
\hline Scientific-research value & $\Delta$ & $\Delta$ & $\Delta$ & $\Delta$ & $\Delta$ & $\Delta$ & $\Delta$ & $\Delta$ & $\Delta$ & $\Delta$ & $\Delta$ & $\Delta$ & $\Delta$ & $\Delta$ & $\Delta$ & $\Delta$ & $\Delta$ & $\Delta$ & $\Delta$ \\
\hline
\end{tabular}

The cartographically presented values of the assessment of the cultural significance of the site in the Golubac-Radujevac sector range only within category I of values from $0-20$. Within that category, two subgroups of values from 10-12 and 13-17 were singled out. This provides a more precise presentation of the range of summarized values of ratings within the group (Table 7, Figure 4). As with the previous two maps (Figures 2 and 3), the sign method was used, and the color of the sign achieved clarity, thus maintaining the comparability of the basic and thematic content of the map.

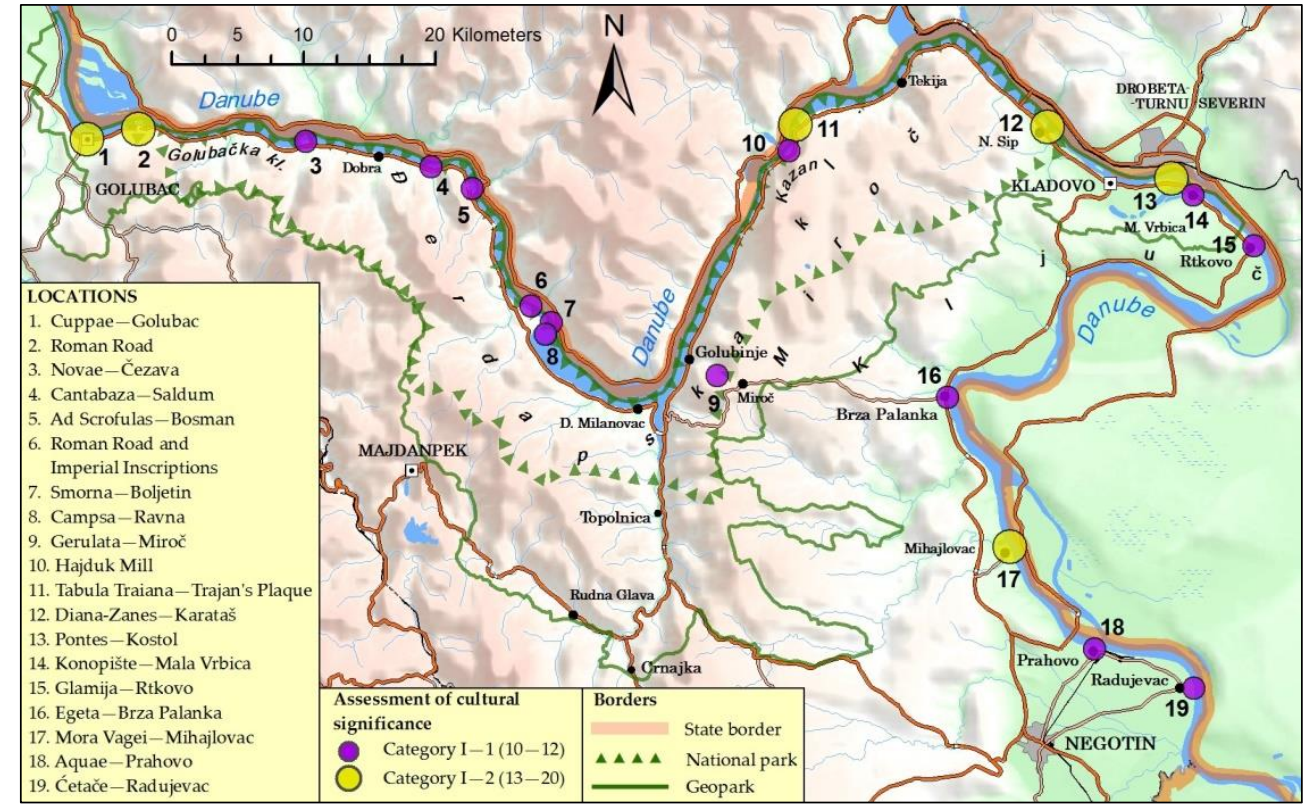

Figure 4. Assessment of cultural significance. 
II-2 Robustness assessment was carried out based on nine indicators evaluated: rates 0-4 (indicators 1 and 2) and rates 0-5 (indicators 3-9) (Table 8).

- Cultural asset sensitivity. The degree of sensitivity of extremely valuable cultural monuments is conditioned by their poor condition or specific location (submerged localities, visibility of localities from a distance, etc.). The average score for the sites is 2 , which indicates considerable sensitivity.

- $\quad$ Reparation state. Fortresses require significant reparations. The average score for all is less than 1 (partially poor state).

- Existence of the cultural asset management plan. The area of the Golubac-Radujevac sector is covered by a lot of planning documents. These are the Spatial Plan of the Republic of Serbia from 2021 to 2035 [4]; Spatial plan of the special purpose area of the National Park "Đerdap", 2020 [31]; Master plan of the cultural-historical route "Route of the Roman Emperors" [3]; Master plan of the tourist destination "Donje Podunavlje" [2]; Detailed regulation plan for the revitalization of the fortress "Golubacki grad" 2009 [32]; Spatial plans of the municipalities of Golubac, Majdanprek, Kladovo, Negotin [33-36] encompassing the cultural assets of the Danube Limes region Golubac-Radujevac. Although these strategic plans point out the importance of tourism development and provide guidelines for the perspective development of this nationally important area, the results of the planned activities are low. Therefore, the average score for these sites is very low and amounts to 1. Development plans are not fully implemented and are often subject to revisions and refinements.

- Regular monitoring and maintenance. The average rating for these sites is very low and amounts to less than 1, so it is necessary to establish constant monitoring and maintenance as soon as possible.

- Potential for investment and consultation of key stakeholders. The average rating of this indicator is 2. The cultural assets of the Danube Limes, together with the surrounding nature, form a specific environmental complex, calls for more investment. The national and international significance of this destination must include the coordination of numerous actions within the conservation of cultural assets and investments for the development of transportation infrastructure, construction of additional tourist facilities and environmental protection, etc. Emphasis should be placed on complementary contents from the environment, which should be harmonized and developed together with the arrangement and protection of these sites. The complexity of cultural and natural contents as a total offer provides larger and synchronized actions in financing. Within that, the existence and implementation of legislation contribute to more stable investment.

- The potential of a negative impact of a large number of visitors on the physical condition of the cultural asset. The specificity of the location and current condition of several localities limits the possibility of a negative impact of visitors on the condition of the cultural asset. The average score of this indicator is 2 and implies a medium possibility of impact. It is necessary to conduct more adequate control and protection from possible negative impacts, especially on sites that are in poorer physical condition.

- The potential of a negative impact of a large number of visitors on the lifestyle and cultural traditions of the local community. A large number of localities are isolated and located outside the populated area, which reduces this type of adverse impact. The average score of this indicator is 1 and indicates a medium possibility of impact.

- The possibility that modification as part of product development has a negative impact on the physical condition of the cultural asset. The average score of this indicator is less than 1 and indicates a small possibility of impact. Cultural assets are under state protection, so the possibility of negative modification is limited. Legal acts, spatial and master plans, plans of special-purpose areas, etc. prescribe the method of protection. The modification is included in the legislative and planning activities, but it exclusively envisages the positive effects of the protection of the site and the surrounding green areas, pedestrian paths, dedicated infrastructure equipment, etc. 
Such actions should be strictly controlled, so that degradation of the area does not occur. The control should include activities related to landscaping, so as not to jeopardize the authenticity of any site and its immediate area.

- The possibility that modification as part of product development has a negative impact on the lifestyle and cultural traditions of the local community. The current level of involvement of various forms of culture and tradition in the tourist offer of this area is low. The average score of this indicator is less than 1 (low possibility of impact). The quality of life of the local population, especially the local traditions, should be promoted within the tourist offer.

Table 8. Robustness assessment.

\begin{tabular}{|c|c|c|c|c|c|c|c|c|c|c|c|c|c|c|c|c|c|c|c|}
\hline $\begin{array}{l}\text { Robustness Assessment/ } \\
\text { Management Sector }\end{array}$ & & & & & & $\stackrel{n}{0}$ & & & & & $\stackrel{0}{\Xi}$ & & & & & & & & \\
\hline $\begin{array}{r}\Delta 5 \\
\Delta 4 \\
\Delta 3 \\
2 \\
\Delta 1 \\
\triangle 0\end{array}$ & 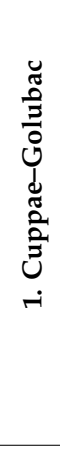 & 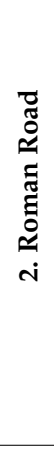 & 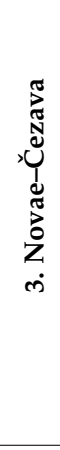 & 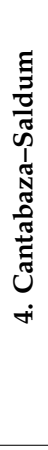 & 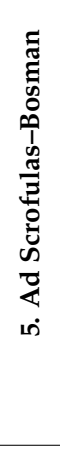 & 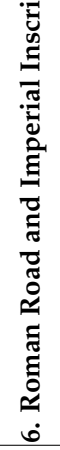 & 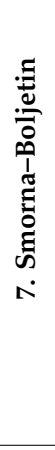 & 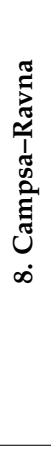 & 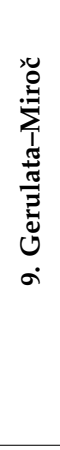 & 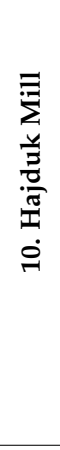 & 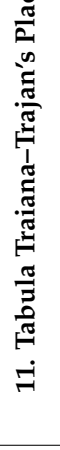 & 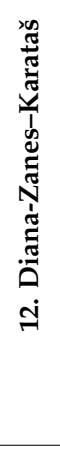 & 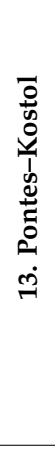 & 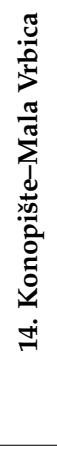 & 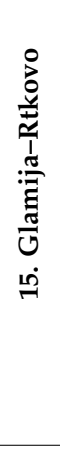 & 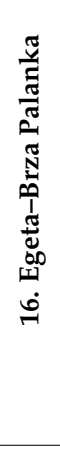 & 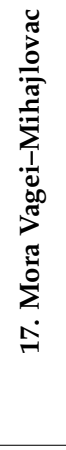 & 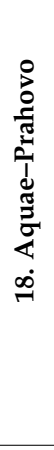 & 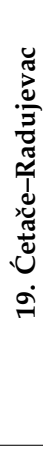 \\
\hline Cultural asset sensitivity & $\Delta$ & $\Delta$ & $\Delta$ & $\Delta$ & $\Delta$ & $\Delta$ & $\Delta$ & $\Delta$ & $\Delta$ & $\Delta$ & $\Delta$ & $\Delta$ & $\Delta$ & $\Delta$ & $\Delta$ & $\Delta$ & $\Delta$ & $\Delta$ & $\Delta$ \\
\hline Reparation state & $\Delta$ & $\Delta$ & $\Delta$ & $\Delta$ & $\Delta$ & $\Delta$ & $\Delta$ & $\Delta$ & $\Delta$ & $\Delta$ & $\Delta$ & $\Delta$ & $\Delta$ & $\Delta$ & $\Delta$ & $\Delta$ & $\Delta$ & $\Delta$ & $\boldsymbol{\Delta}$ \\
\hline $\begin{array}{l}\text { Existence of the cultural asset } \\
\text { management plan }\end{array}$ & $\Delta$ & $\Delta$ & $\Delta$ & $\Delta$ & $\Delta$ & $\Delta$ & $\Delta$ & $\Delta$ & $\Delta$ & $\Delta$ & $\Delta$ & $\Delta$ & $\Delta$ & $\Delta$ & $\Delta$ & $\Delta$ & $\Delta$ & $\Delta$ & $\Delta$ \\
\hline $\begin{array}{l}\text { Regular monitoring } \\
\text { and maintenance }\end{array}$ & $\Delta$ & $\Delta$ & $\Delta$ & $\Delta$ & $\Delta$ & $\Delta$ & $\Delta$ & $\Delta$ & $\Delta$ & $\Delta$ & $\Delta$ & $\Delta$ & $\Delta$ & $\Delta$ & $\Delta$ & $\Delta$ & $\Delta$ & $\Delta$ & $\Delta$ \\
\hline $\begin{array}{l}\text { Potential for investment } \\
\text { and consultation } \\
\text { of key stakeholders }\end{array}$ & $\Delta$ & $\Delta$ & $\Delta$ & $\Delta$ & $\Delta$ & $\Delta$ & $\Delta$ & $\Delta$ & $\Delta$ & $\Delta$ & $\Delta$ & $\Delta$ & $\Delta$ & $\Delta$ & $\Delta$ & $\Delta$ & $\Delta$ & $\Delta$ & $\Delta$ \\
\hline \multicolumn{20}{|c|}{ Potential of the negative impact of a large number of visitors on: } \\
\hline $\begin{array}{l}\text { Cultural asset } \\
\text { physical state }\end{array}$ & $\Delta$ & $\Delta$ & $\Delta$ & $\Delta$ & $\Delta$ & $\Delta$ & $\Delta$ & $\Delta$ & $\Delta$ & $\Delta$ & $\Delta$ & $\Delta$ & $\Delta$ & $\Delta$ & $\Delta$ & $\Delta$ & $\Delta$ & $\Delta$ & $\Delta$ \\
\hline $\begin{array}{l}\text { Lifestyle and cultural } \\
\text { traditions of the } \\
\text { local community }\end{array}$ & $\Delta$ & $\Delta$ & $\Delta$ & $\Delta$ & $\Delta$ & $\Delta$ & $\Delta$ & $\Delta$ & $\Delta$ & $\Delta$ & $\Delta$ & $\Delta$ & $\Delta$ & $\Delta$ & $\Delta$ & $\Delta$ & $\Delta$ & $\Delta$ & $\Delta$ \\
\hline $\begin{array}{l}\text { Cultural asset } \\
\text { physical state }\end{array}$ & atial $\mathrm{f}$ & r the & nodif & Potential for the modification as a part of product development to have a negative impact on: & as a $\mathrm{F}$ & art of & prod & ct de & lopn & ent to & have & nega & ive $\mathrm{i}$ & npact & n: & $\Delta$ & $\Delta$ & $\Delta$ & $\Delta$ \\
\hline $\begin{array}{l}\text { Lifestyle and cultural } \\
\text { traditions of the } \\
\text { local community }\end{array}$ & $\Delta$ & $\Delta$ & $\Delta$ & $\Delta$ & $\Delta$ & $\Delta$ & $\Delta$ & $\Delta$ & $\Delta$ & $\Delta$ & $\Delta$ & $\Delta$ & $\Delta$ & $\Delta$ & $\Delta$ & $\Delta$ & $\Delta$ & $\Delta$ & $\Delta$ \\
\hline
\end{tabular}

The cartographically presented values of robustness assessments are within the defined scale of tourist valorization of sub-indicators. Values are represented only within category II 20-40 (medium attractiveness). To better understand the values within this category, they were analyzed and visualized within 3 subgroups: $20-24,25-29$, and $30-35$. This provides a clear and more accurate presentation of the range of summarized values of ratings within category II (Table 8, Figure 5). Numerical values are represented using the method of signs, whose scalars are determined by the value within the group and the color of the sign achieves clarity. The basic and thematic content of the map is comparable to the contents of previous maps.

The results of tourist valorization of all 19 cultural assets of the Danube Limes in Serbia's Golubac-Radujevac region, show that the total value of the sub-indicator of the tourism sector is 30 , and the value of the sub-indicator of cultural assets management is 38 . This means that their position category $M(m, m)$,i.e., has medium values of both 
sub-indicators (category 20-40) for the tourism sector and cultural property management. Despite the good aggregate rating of all 19 localities, it is necessary to do more towards the development of this important attractive area. Better affirmation of all 19 cultural assets as complex units of the same thematic field can be achieved by eliminating the impact of negative factors, which are defined as such through this research. At the same time, the development of incentive indicators should be promoted.

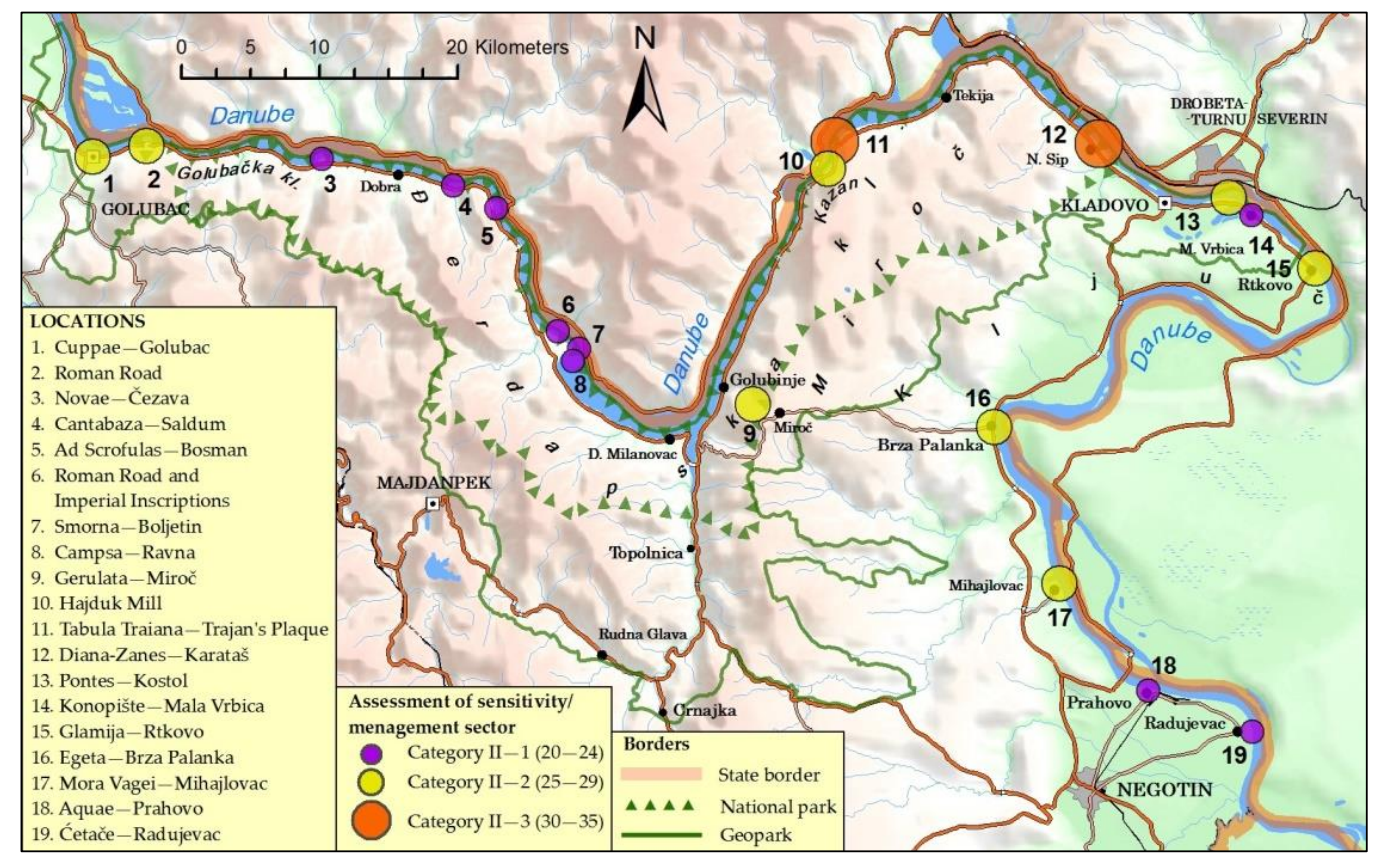

Figure 5. Robustness assessment.

Observed individually, their position in the matrix of cultural assets of the Danube Limes in Serbia's Golubac-Radujevac region is as follows:

1. Category M (h,h)_localities: Diana-Zanes, Tabula Traiana, Trajan's Plaque and the Roman Road. The high values of both sub-indicators (tourism sector and cultural assets' management) indicate that they can be included in the tourist offer of this destination as an exceptional tourist product.

2. Borderline categories $M(h, h)$ and $M(h, m)$ localities: Cuppae and Pontes. Both localities have a high value of sub-indicators of the tourism sector and different values of sub-indicators of cultural assets' management (high and medium).

3. Category $\mathrm{M}(\mathrm{m}, \mathrm{h})$ locality: Mora Vagei. They are characterized by the medium value of the sub-indicators of the tourism sector, and the high value of the sub-indicators of cultural assets' management characterizes this locality.

4. Category M (m,m) localities: Egeta, Hajduk Mill, Glamija, Konopiste, Gerulata, Aquae, Ćetače and Novae. They are characterized by the medium value of the tourism sector sub-indicator and the medium value of the cultural assets' management sub-indicator.

5. Category M $(1, \mathrm{~m})$ localities: Cantabaza, Ad Scrofulas, Roman Road and Imperial Inscriptions, Smorna and Campsa. The sites have the lowest value of market attractiveness and the medium value of robustness, considering that these are submerged sites after the construction of the hydroelectric power plant (Figure 6). 


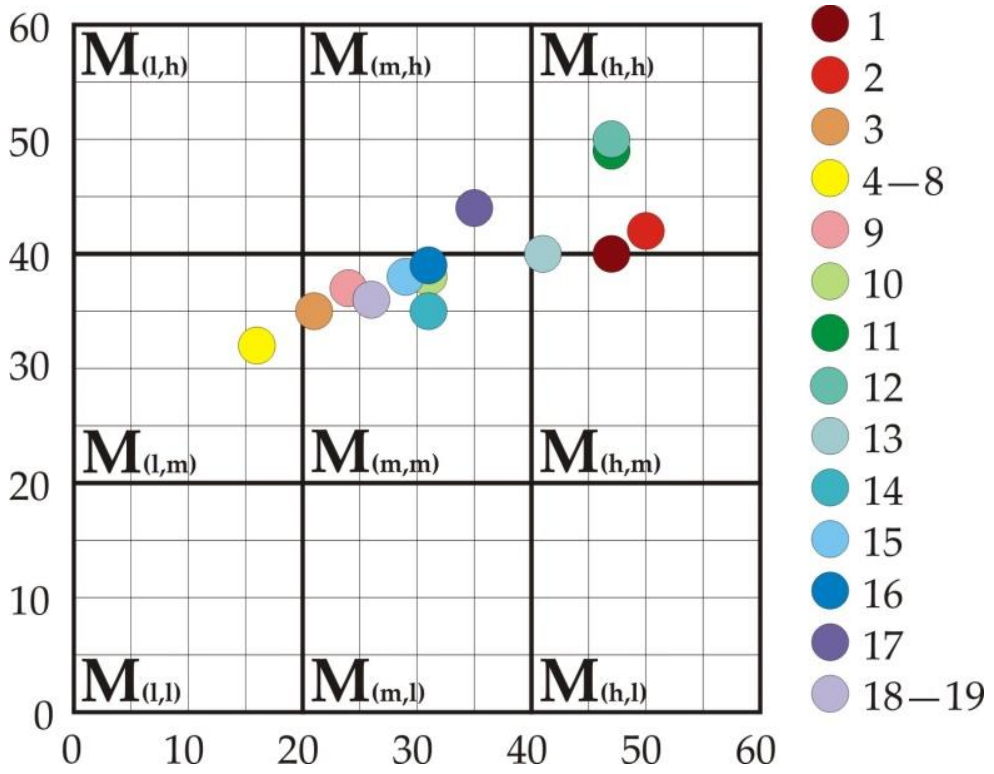

Figure 6. Position of cultural assets in the matrix according to Hilary Du Cros model $[5-7,28,29]$ (1. Cuppae-Golubac, 2. Roman Road, 3. Novae-Čezava, 4. Cantabaza-Saldum, 5. Ad ScrofulasBosman, 6. Roman Road and Imperial Inscriptions, 7. Smorna-Boljetin, 8. Campsa-Ravna, 9. Gerulata-Miroč, 10. Hajduk Mill, 11. Tabula Traiana-Trajan's Plaque, 12. Diana-Zanes-Karataš, 13. Pontes-Kostol, 14. Konopište-Mala Vrbica, 15. Glamija-Rtkovo, 16. Egeta-Brza Palanka, 17. Mora Vagei-Mihajlovac, 18. Aquae-Prahovo, 19. Ćetače-Radujevac).

By classifying the values of indicators/sub-indicators of cultural assets and determining their position within the matrix, the assets are rated against their potentials. Under the tourism development management planning, it is possible to use the resulting matrix to categorize the assets against the degree of attractiveness. The following localities are categorized according to the market attractiveness, tourist attractiveness, cultural significance and robustness:

1. Primary tourist attractions: Diana-Zanes-Karataš; Tabula Traiana-Trajan's Plaque, Roman Road, Cuppae-Golubac and Pontes-Kostol.

2. Secondary tourist attractions: Mora Vagei-Mihajlovac, Egeta-Brza Palanka, Hajduk Mill, Glamija-Rtkovo, Konopiste-Mala Vrbica, Gerulata-Miroč; Aquae-Prahovo, Ćetače-Radujevac and Novae-Čezava.

3. Reasearch potentials: Cantabaza-Saldum, Ad Scrofulas-Bosman, Roman Road and Imperial Inscriptions, Smorna-Boljetin and Campsa-Ravna.

Under the categorization established in this manner, the localities become notable against their attractiveness and representativeness, and ambience value and preservation in particular.

Planning and managing the process of protection for this heritage as the resource for the development of a local and broader community and improving the quality of life is necessary through the preservation of spatial context and the integrity of a historical location [1]. Apart from the historical, construction, aesthetic and ambience significance, the cultural assets also hold a societal value; tourism is the means for promoting culture and knowledge in a society [9].

"Cultural heritage is a common good passed from previous generations as a legacy for those to come" [37]. The protection and promotion of cultural heritage implies the inclusion of local communities in activities regarding cultural heritage, to raise the sense of having a common history and sharing similar values. The inclusion of the population in the preservation, interpretation and presentation of heritage yields the knowledge of history, culture, sustainable development, legal framework, restoration techniques, heritage presentation methods, which contribute to societal heritage protection, since the sense of 
unity builds the feeling of connection and belonging, a respect of historical heritage and economic and social security, etc. Acquiring knowledge and building skills improve the awareness of the societal and economic significance of culture and heritage and promotes the appropriate views. Transparency of activities, education, engagement and inclusion of the population in the process of decision-making on practical issues, within the particular projects of the institutions and organizations in the field of heritage, improves the reach of the implementation [38].

Engaging the local population through employment, volunteering, participation in the organization of cultural and sporting events, education and professional development, marketing, promotion and other activities in tourism is necessary both for the economy, society and the environment. The development of complementary services and enrichment of space with tourist content aimed at leisure, recreation and cultural activities would improve the level of offers and provide better promotion of the cultural assets of this area.

Marketing and promotion have a major role in tourism. The interpretation and presentation of cultural and natural heritage helps people understand the importance of heritage and opt to appreciate and protect it. Focusing on the comprehension of cultural heritage in the awareness of the broader public and changing their relationship with monumental heritage requires the inclusion of the local and broader community. The constant process of promoting cultural heritage, developing an understanding of the needs and care required to preserve the heritage value is required to create a collective memory within the community. The cultural heritage localities along the Danube from the Roman Empire period are a testament to this history and represent valuable archaeological heritage and historic constructions.

Cultural heritage plays a significant role in creating and strengthening economic and social values, because it: promotes participation from citizens in public life; improves the quality of life and welfare of individuals and their communities; strengthens the sense of belonging to the broader community; develops skills, knowledge, creativity and innovation; impacts education and professional development; has a positive impact on sustainable development; and provides the opportunity of various employment types; etc. Human knowledge on the cultural heritage localities along the Danube, as the heritage values from the Roman Empire period, is a prerequisite for valuing, protecting and preserving its heritage [39] (pp. 154-165).

The geographic position and natural traits of the Danube riverbank in Serbia impacted the positioning of Roman military localities and infrastructure as a significant defense system of that era and communication in an economic and cultural sense. The uniqueness of these localities indicates the importance of this area as the location of key historical events from the Roman Empire period. The presentation and promotion of this destination are under the jurisdiction of tourist organizations and municipalities of Golubac, Majdanpek, Kladovo, and Negotin. The promotion and distribution of tourism services, together with monitoring the requirements of tourism demand and tourism trends, happen in the digital environment. Information from websites and social networks are the most important factors to an individual when selecting a vacation destination. Internet promotions contain detailed information advertising the complete tourist offer and attractiveness of the tourist destination. The contents are supplemented by representative graphical animations. The advantage of the internet and social networks used for the tourism economy include: reduced costs, a growing market, and the possibility of continuous communication with potential tourists [40].

Information on tourist attractiveness, accessibility, tourism offers, and tourism organization impact the positive product image creation and its most favorable positioning. Tourists may use mobile applications and recommendations from social networks to obtain information on this destination regarding: options for shorter vacations throughout the year, authentic experiences (natural and cultural-historical), preserved and protected nature, local culture, sporting-leisure and educational content, vicinity of other tourist destinations, destination safety and security, transport links and destination accessibility (by 
land and water), accessibility and movement options over the tourist destination, tourist services quality and variety, the quality of lodging and board, etc.

Apart from the promotion of cultural heritage localities along the Danube from the Roman Empire era, the offer of tourist organizations from the above municipalities includes a wide range of cultural and sporting events, concerts, theater shows, art classes, land and river tours to cultural, religious and natural attractions that complement the historical heritage, options for sports fishing, gastronomy, visits to vine cellars, panoramic sightseeing, windsailing, etc. Positive effects of tourist organizations' activities are also reflected through the perceived importance of the citizens' education and promotion of the local population inclusion program for work in the tourist sector.

\section{Discussion and Conclusions}

Tourist valorization of cultural assets of the Danube Limes in Serbia's GolubacRadujevac region is the basis for understanding the potential and opportunities for tourism development of this destination. The results of the research using the methodology applied in this paper indicate the significant potential of this area, as well as the necessity to take concrete actions in order to improve the tourist offer and affirm all of the localities as a whole. The significance of these cultural assets is their historical role as locations within the important international Danube tourist destination, as well as within national tourist destinations, which with their attractive natural resources testify to the heritage of ancient civilizations. Although the Roman localities of this destination are recognizable within the Danube region, especially within the Djerdap National Park of the Djerdap Geopark, the area is not adequately positioned. The obtained mean values of the sub-indicators $(\mathrm{M} \mathrm{m}, \mathrm{m})$, the tourist sector's cultural property management, are conditioned by the high rating of the following sites: Cuppae, Roman Road, Tabula Traiana, Diana-Zanes, Pontes and Egeta, in relation to the others.

The Roman heritage along the banks of this part of the Danube Limes is of great architectural importance, which, together with unique, naturally preserved and protected resources (especially in the Djerdap Gorge), makes it possible to better streamline the flow of tourism. The area's natural ambient diversity is a complementary value to the cultural heritage of the Danube Limes in Serbia and attractiveness of the area is an important stimulus. Linking individual sites through a common offer, creating additional cultural attractions and events, the branding and modern marketing of destinations, and greater material investment through the conservation of archaeological localities would impact the development of the territory's identity. Developing an awareness of heritage and its importance, especially among the local population, would contribute to their greater engagement in the revival of tourism activity. It is necessary to ensure the sustainability of cultural heritage through complementarity in the following ways: planning and management of cultural assets and investment potential, planned implementation of service facilities, improvement of physical access to places of historical value (institutionalized investment in infrastructure, transportation and tourism), and the monitoring and protection of the site area.

Specific traits of cultural assets, functional connections with the territory of unique natural beauty (Djerdap National Park and Djerdap Geopark) and other cultural-historical assets (Golubac fortress) demand a definition of tourism development objectives over a certain period. Tourism development should be managed in a controlled and sustainable manner, integrated into the national planning process, to promote and achieve the objectives of economic, social, and environmental development [41]. Planning needs to identify opportunities and limitations to development and minimize potential negative impacts. Tourism valorization of cultural assets, using the Hilary Du Cros model, provided an evaluation of the real situation and offered guidelines for activities to be taken to enable further tourism development.

Tourism planning needs to be focused with defined measures for controlling tourism activities on this part of the Danube Limes. Uniqueness, attractiveness, spatial recognition, and permanence are the foundations for building offers for tourists and generating demand 
for this destination. Within sustainable development planning, it is required to define the concept of tourism feasibility. This would establish a harmony between economic, societal, cultural, institutional, and environmental dimensions of sustainability. The feasibility concept in tourism is a complex procedure, involving various, often conflicting indicators, which are hard to harmonize and control. This requires co-operation within multidisciplinary teams of experts and their constant education. "Tourism development, more so than in other fields, is subject to the quality of the environment, its natural and cultural values, and traits, since the degree of the environment preservation and attractiveness has a direct impact on the tourism development opportunities in the subject area" [42] (p. 64). For that reason, it is necessary to determine a potential overload in the area. Determining the bearing capacity limit would alleviate the potentially harmful effects of tourism on natural resources, cultural assets, the enjoyment of visitors, local population livelihoods, economy, and the tradition and culture of the area.

Tourist capacity is the optimum maximum number of tourists simultaneously visiting a tourist destination, to avoid unacceptable environmental, physical, economic, and socio-cultural consequences, without diminishing the visitors' satisfaction [43]. The tourist capacity concept facilitates establishing an equilibrium between environment protection and economic development, setting developmental limitations, continuous monitoring, and evaluation of the sustainable development of tourism. The quantity of tourism attractiveness "yielded" by the area is subject to the traits of the broader territory. Spatial traits and factors impacting spatial limitations and opportunities are to be determined first against this, followed by the spatial activities that happen over the subject territory. Adjustment to the modern tourism trends needs to be focused on preserving and protecting the locality. The volume of visitors and activities need to be harmonized with the environmental properties of the area.

The valuation of tourist capacity covers area properties, natural limitations, opportunities and benefits that a user may obtain from the territory, number of visitors, the impact on living standards, the experience and expectations of visitors, local community way of life, level of development, availability of the leisure contents, scale of natural and original traits of the area, and boundaries of acceptable utilization, etc. The control of tourist development may remedy or diminish potential negative impacts: changes to the characteristic traits of cultural assets and ambiance values, degradation of tourism attractiveness, unplanned development of auxiliary buildings and supplementary content, jeopardizing access to the localities, and endangering the environment, etc.

The capacity of this destination has not been quantified thus far; instead, it has been descriptively indicated in the National and Geopark. Access to these localities is free, without limitations and monetary compensation. The tourism development capacity needs to be defined in a quantitative sense over the upcoming period, under sustainable development planning. The capacity concept application has been achieved only over the Golubac fortress area, where the number of visitors (capacity limit) is being determined per individual zones. This simultaneously determines the capacity for the Roman Road, situated under the Golubac fortress (the road remains may be seen in the fortress foothill).

Under the tourism development and measures for the preservation of cultural assets and natural resources, the issue of economic valorization arises: if the preservation of cultural assets and nature may benefit from their use for tourism. The readiness of the tourists to pay to experience a certain state of a cultural asset and natural resource is a part of the support to their preservation [44]. Individual cultural assets, due to their attractive location and high visitation rates, have a high degree of protection. Accesses to certain localities, security-wise, which require a higher level of sporting-recreational preparedness from tourists (e.g., conquering the fortress), require separating the zones and limiting visitors. The readiness of the tourists to pay additional fees to access localities indicates certain aspects of their utility (tourist, recreational, educational, etc.).

The tourism capacity concept is harmonized with the planning documents of national importance. Under the "Itinerarim Romanum Serbiae" Project, the envisioned plan "Serbia 
2025" included the study "Works on the Tourism Infrastructure Development at Archeological Localities". The goal of the study was to link all localities along the route for the tourism promotion of Serbia and yield economic benefits at national and local levels [45]. Additionally, the projects covering the conservation works are being implemented for the remaining fortifications: Glamija-Rtkovo, Egeta-Brza Palanka, Mora Vagei-Mihajlovac, Ćetače-Radujevac, and Konopište-Mala Vrbica. The projects involve experts from competent institutions of national, regional, and local importance. The works cover archaeological determination of the current state, architectural, geodetic and photo-grammetric acquisitions, and preservation-restoration works. The completion of the works would protect the representative cultural assets with a high-level of authenticity, to appropriately represent the cultural heritage [46].

The localities covered in these planning documents, as the cultural heritage areas are defined as landscape units with the protected environment $[2-4,31-36,45,46]$. This establishes the zones of immovable cultural assets' protection, with a spatial scope and various degrees of spatial protection and use and permitted activities defined. This also includes the modalities of use by the visitors. After the completion of works, the capacity will be defined in line with the above. The capacity would be determined against the specific properties of individual cultural assets (location, physical state, specific environment, protection regime, etc.). The capacity limit of the area and environment for the entire territory will be determined according to the capacities of individual zones and units. In this effort, we need to consider the vicinity of other cultural (Golubac fortress) and natural attractions (Djerdap National Park and Djerdap Geopark), with intertwining capacities. This increases the complexity of determining the capacity for the localities that are intertwined or in close vicinity; however, with the clear objective to protect cultural and natural assets.

The research indicates the requirement of modern, complex comprehension of planning, regulation, protection, conservation, and presentation of Roman localities. The existing potential for the development of tourism in the part of the Danube Limes in Serbia have not been well utilized. In addition to the need to improve the attractiveness and accessibility of sites, it is necessary to add innovative content, build info-centers, improve the study and protection of sites, and build and arrange panoramic views and rest areas, etc. Panoramic and ambient areas should be completed with modern panels showing the information on sites, position, context and significance (e.g., Tabula Traiana; submerged sites in the area of Djerdap gorge, etc.). It is necessary to improve marketing and organize programs for the interpretation of the authentic significance of cultural assets in relation to the different interests of visitors (geographical, historical, archaeological, architectural, artistic, etc.). The promotion of a tourist destination should include a visual presentation using multimedia technology. Connecting the Danube Limes site, the route of only one part of the ancient Roman itinerary, creating a tourist product and promoting it, includes significant cartographic support. Cartographic visualization of real and virtual geographic territory should have an empowering impact on the development of tourism. The development of interactive maps with accompanying multimedia effects, the influence of the Internet and the use of smart phone applications for tourism purposes, should enable the integration of heterogeneous data sources into a unique and interesting product. Through the internet, the presentation of tourist content contributes to the global availability of information to a large number of users. The contents of tourist maps should be attractive and provide users with a quick insight and understanding of information.

Cartographic visualization, as information support, during the research enabled the presentation of results within the planning of tourist development. Cartographic visualization of geospatial information on the significance of sub-indicators of the cultural assets within the area of the Danube Limes in Serbia yielded concise content in a graphically unique manner. The maps were accompanied by a visually integral image of a specific space and, as such, were a source of information for the analysis of thematic content [47]. Graphical and visual presentation of summarized values of 29 sub-indicators, within four groups, using the sign method, has achieved a cognitive interpretation. A separate map 
has been produced for each of the sub-indicators' category. Within the I-tourism sector of the map: 1. Assessment of the market attractiveness of cultural assets; 2 . Assessment of the factor of significance in the design of a tourist product, and in the framework of II-management of cultural assets maps: 3. Assessment of cultural significance and 4. Assessment of robustness.

By cartographic visualization of the obtained and processed data of individual indicators (Figures 2-5), the range of values for each locality is clearly seen. This achieves an obvious comparability of the connection between the location, the attractiveness and the preservation of the cultural assets. By evaluating the cultural assets of the Danube Limes in Serbia, an analysis and assessment of the real situation was performed, and guidelines were given for the necessary measures to be taken for better and more comprehensive development of tourism in this destination.

Author Contributions: Conceptualization, M.S.; Data curation, S.D., D.Dj. and R.B.; Formal analysis, T.J., Lj.Ž., T.G., D.D.B., T.N.T. and J.A.S.; Investigation, Lj.Ž., T.G., D.D.B., T.N.T. and J.A.S.; Methodology, M.S.; Supervision, T.J. and M.R.; Validation, M.R.; Visualization, J.M.J., M.S., S.D., D.Dj. and R.B.; Writing-original draft, J.M.J.; Writing—review and editing, J.M.J. All authors have read and agreed to the published version of the manuscript.

Funding: This research received no external funding.

Institutional Review Board Statement: Institutional Review Board Statement is not required for this paper in Serbia.

Informed Consent Statement: Informed consent was obtained from all subjects involved in the study.

Data Availability Statement: Data available on request due to restrictions.

Conflicts of Interest: The authors declare no conflict of interest.

\section{References}

1. Vujović, S. Kako Očuvati i Koristiti Kulturno Nasledje—Doprinos Vekova Bača; Pokrajinski Zavod za Zaštitu Spomenika Kulture, Petrovaradin: Novi Sad, Serbia, 2016.

2. Naučno-Istraživački Centar Ekonomski Fakultet. Master Plan Turističke Destinacije "Donje Podunavlje"; Ekonomski Fakultet: Beograd, Serbia, 2007. Available online: https:// futurehospitalityleaders.files.wordpress.com/2012/08/master-plan-turistickedestinacije-donje-podunavlje.pdf (accessed on 1 February 2021).

3. Ekonomski Fakultet. Master Plan Kulturnoistorijske Rute "Put Rimskih Careva"; Ekonomski Fakultet: Beograd, Serbia, 2007. Available online: https://futurehospitalityleaders.files.wordpress.com/2012/08/master-plan-kulturnoistorijske-rute-putrimskih-careva.pdf (accessed on 3 February 2021).

4. IAUS; Univerzitet u Beogradu—Geografski Fakultet i Arhitektonski Fakultet; Saobraćajni Institut CIP; JP Zavod za Urbanizam Vojvodine; GDI SOLUTIONS. Prostorni Plan Republike Srbije od 2021. do 2035-Nacrt; Ministarstvo Gradjevinarstva, Saobraćaja i infrastructure: Beograd, Serbia, 2021. Available online: https://www.mgsi.gov.rs/sites/default/files/PPRS\%20Nacrt.pdf (accessed on 15 May 2021).

5. Du Cros, H.; McKercher, B. Cultural Tourism, 3rd ed.; Routledge: London, UK, 2020. [CrossRef]

6. Du Cros, H. Planning for Sustainable Cultural Heritage Tourism in Hong Kong. In Final Report to the Lord Wilson Heritage Trust Council; SAR: Hong Kong, China, 2000.

7. Du Cros, H. A New Model to Assist in Planning for Sustainable Cultural Heritage Tourism. Int. J. Tour. Res. 2001, 3, 165-170. [CrossRef]

8. Hernández, J.B.; Juan i Tresserras, J. Gestión del Patrimonio Cultural, 4th ed.; Ariel Patrimonio: Barcelona, Spain, 2008 ; pp. 2-23.

9. Ramírez-Guerrero, G.; García-Onetti, J.; Arcila-Garrido, M.; Chica-Ruiz, J.A. A Tourism Potential Index for Cultural Heritage Management through the Ecosystem Services Approach. Sustainability 2021, 13, 6415. [CrossRef]

10. Dragouni, M.; Fouseki, K. Drivers of community participation in heritage tourism planning: An empirical investigation. J. Herit. Tour. 2018, 13, 237-256. [CrossRef]

11. International Centre for the Study of the Preservation and Restoration of Cultural Property (ICCROM). A Story of Change; Success Stories and Lessons Learnt from the Culture Cannot Wait: Heritage for Peace and Resilience Project; ICCROM: Roma, Italy, 2021. Available online: https://www.iccrom.org/sites/default/files/publications/2021-02/astoryofchange.pdf (accessed on 19 December 2021).

12. Jovanović, M.J.; Janković, T.; Stojanović, M. Kartografska Podrška Održivom Razvoju Turizma. In Zbornik Radova sa Naučnog Skupa Planska i Normativna Zaštita Prostora i Životne Sredine; APP Srbije \& Univerzitet u Beogradu-Geografski Fakultet: Beograd, Serbia, 2020; pp. 167-173. 
13. Korać, M.; Golubović, S.; Mrđić, N.; Jeremić, G.; Pop-Lazić, S.; Jilek, S.; Breeze, J.D. Roman Limes in Serbia. In Introductory Part_Frontiers of the Roman Empire; Institute of Archeology: Belgrade, Serbia, 2014.

14. Danube Limes. Available online: https://www.danube-limes.eu/a-vilagoroksegrol/ (accessed on 9 February 2021).

15. UNESCO. Available online: https://whc.unesco.org/en/tentativelists/6475/ (accessed on 11 February 2021).

16. Ployer, R.; Polak, M.; Schmidt, R. The Frontiers of the Roman Empire. In A Thematic Study and Proposed World Heritage Nomination Strategy; ICOMOS: Vienna, Austria; Nijmegen, The Netherlands; Munich, Germany, 2017.

17. UNESCO. Available online: https://whc.unesco.org/en/list/430/ (accessed on 11 February 2021).

18. Global Geoparks Network. Available online: https://globalgeoparksnetwork.org/?page_id=5 (accessed on 9 February 2021).

19. Eder, W.; Patzak, M. Geoparks-Geological attractions: A tool for public education, recreation and sustainable economic development. Epis. J. Int. Geosci. 2004, 27, 162-164. [CrossRef] [PubMed]

20. Zouros, N. The European Geoparks Network. Geological heritage protection and local development. Epis. J. Int. Geosci. 2004, 27, 165-171. [CrossRef]

21. Bandarin, F.; Hosagrahar, J.; Albernaz, F.S. Why development needs culture. J. Cult. Herit. Manag. Sustain. Dev. 2011, 1, 15-25. [CrossRef]

22. Roders, A.P.; Von Oers, R. Editorial: Initiating cultural heritage research to increase Europe's competitiveness. J. Cult. Herit. Manag. Sustain. Dev. 2011, 1, 84-95. [CrossRef]

23. Chen, C.; Chen, P. Resident Attitudes toward Heritage Tourism Development. Tour. Geogr. 2010, 12, 525-545. [CrossRef]

24. Benton, G. Visitor Perceptions of Cultural Resource Management at Three National Park Service Sites. Visit. Stud. 2011, 14, 84-99. [CrossRef]

25. Guerrero, G.R.; Garrido, M.A.; Ruiz, A.C.; López, D.B. Concrete as Heritage: Social Perception and its Valuing-The Zarzuela Hippodrome Case. Structural Studies, Repairs and Maintenance of Heritage Architecture XVI. WIT Trans. Built Environ. 2019, 191, 17-27. [CrossRef]

26. Ramírez-Guerrero, G.; García-Onetti, J.; Chica-Ruiz, J.A.; Arcila-Garrido, M. Social appreciation for the improvement of tourism management of 20th-century heritage: A methodological proposal. Int. J. Cult. Tour. Hosp. Res. 2021, 15, 522-546. [CrossRef]

27. Abeal Vázquez, J.P.; Tirado-Valencia, P.; Ruiz-Lozano, M. The Impact and Value of a Tourism Product: A Hybrid Sustainability Model. Sustainability 2021, 13, 2327. [CrossRef]

28. McKercher, B.; Ho, P.S.Y.; Du Cros, H. Relationship between tourism and cultural heritage management: Evidence from Hong Kong. Tour. Manag. 2005, 26, 539-548. [CrossRef]

29. Marković, J.J.; Petrović, D. Turistička valorizacija arheološkog nalazišta “Viminacijum” prema modelu Hilari du Kros. In Zbornik Radova Departmana za Geografiju, Turizam i Hotelijerstvo; Univerzitet u Beogradu-Geografski Fakultet: Beograd, Serbia, 2012; pp. 248-262.

30. Terzić, A. Perspektive Razvoja Kulturne Rute "Tvrdjave na Dunavu” u Funkciji Obogaćivanja Turističke Ponude Srbije; Geografski Institute, Jovan Cvijić SANU: Beograd, Serbia, 2014.

31. IAUS; JP Zavod za Urbanizam Niš; JUGINUS. Prostorni Plan Područja Posebne Namene Nacionalnog Parka "Djerdap", Rani Javni uvid; Ministarstvo Gradjevinarstva, Saobraćaja i Infrastrukture, Sektor za Prostorno Planiranje i Urbanizam: Beograd, Serbia, 2020. Available online: https://www.mgsi.gov.rs/sites/default/files/PPPN\%20DJerdap\%20rani\%20javni\%20uvid.pdf (accessed on 25 February 2021).

32. ECOlogica Urbo. Strateška Procena Uticaja na Životnu Sredinu Plana Detaljne Regulacije za Revitalizaciju Tvrđave "Golubački Grad"; ECOlogica Urbo: Kragujevac, Srbija, 2009. Available online: http://www.golubac.org.rs/wp-content/uploads/2018/02/ Planovi\%20golubac/Strateska\%20tvrdjava\%20Golubac\%20decembar.pdf (accessed on 25 February 2021).

33. Arhiplan. Prostorni Plan Opštine Golubac; Opštinska Uprava Opštine Golubac: Golubac, Serbia, 2011. Available online: http: / / www.golubac.org.rs/wp-content/uploads/2018/02/Planovi\%20golubac/PPO\%20Golubac\%20PLAN\%20jul\%202011.pdf (accessed on 25 February 2021).

34. Centar za Planiranje Urbanog Razvoja; CEP. Prostorni Plan Opštine Kladovo; Opštinska Uprava Opštine Kladovo: Kladovo, Serbia, 2006. Available online: https:/ / www.kladovo.org.rs/prostorni-plan-optine-kladovo.htm (accessed on 21 February 2021).

35. Opština Majdanpek. Strategija Lokalnog Ekonomskog Razvoja Opštine Majdanpek 2010-2014; Opština Majdanpek: Majdanpek, Serbia, 2013.

36. Univerzitet u Beogradu-Geografski Fakultet; Zavod za Urbanističko Planiranje i Projektovanje Opštine Negotin. Prostorni Plan Opštine Negotin; SO Negotin: Negotin, Serbia, 2011.

37. European Commission, Directorate-General for Education, Youth, Sport and Culture. In European Framework for Action on Cultural Heritage; Publications Office of the European Union: Luxembourg, Luxembourg, 2019. Available online: https://data.europa.eu/ doi/10.2766/949707 (accessed on 2 February 2021).

38. Kisić, V.; Tomka, G. Citizen Engagement and Education-Learning Kit for Heritage CSOs; Evropa Nostra: Hag, The Netherlands, 2018.

39. Council Conclusions of 21 May 2014 on Cultural Heritage as a Strategic Resource for a Sustainable Europe (2014/C 183/08). Off. J. Eur. Union 2014. Available online: https:/ / eur-lex.europa.eu/legal-content/EN/TXT/PDF/?uri=CELEX:52014XG0614(08)\& from $=$ FR (accessed on 28 December 2021).

40. Pindžo, R.; Knežević, M. Priručnik za Planiranje razvoja Turizma u Jedinicama Lokalne Samouprave, Stalna Konferencija Gradova $i$ Opština; Savez Gradova i Opština Srbije: Beograd, Serbia, 2021.

41. Hall, C.M. Tourism Planning: Policies, Processes and Relationship; Prentice Hall: Harlow, UK, 2000.

42. Vujović, S.; Cvijanović, D.; Štetić, S. Destinacijski Koncept Razvoja Turizma; Institut za Ekonomiku Poljoprivrede: Beograd, Serbia, 2012. 
43. World Tourism Organization. Indicators of Sustainable Development for Tourism Destinations, a Guide Book by UNWTO; World Tourism Organization: Madrid, Spain, 2004.

44. Tisdell, C. Valuation of Tourism's Natural Resources; School of Economics, The University of Queensland: Brisbane, Australia, 2003. Available online: https:/ /ageconsearch.umn.edu/record/48962/ (accessed on 2 January 2022).

45. Ekapija. Available online: https://www.ekapija.com/news/3172605/srbija-uredjuje-arheolosku-rutu-putevima-rimskihimperatora-sansa-za-male-privrednike/ (accessed on 2 January 2022).

46. NG Portal. Available online: https:/ / www.ngportal.rs/tag/zavod-za-zastitu-spomenika-kulture-nis/ (accessed on 2 January 2022).

47. Jovanović, M.J.; Tatomirović, S.; Drobnjak, S.; Stojanović, M. Informacioni potencijal kartografske vizuelizacije turističkih vrednosti. In Zbornik Radova sa Naučnog Skupa Lokalna Samouprava u Planiranju i Uređenju Prostora i Naselja; APP Srbije \& Univerzitet u Beogradu-Geografski Fakultet: Beograd, Serbia, 2021; pp. 317-322. 